\title{
NEGLIGENT DISCRIMINATION
}

\section{DAVID BENJAMIN OPPENHEIMER $\dagger$}

\section{INTRODUCTION}

Over the past twenty years the Supreme Court has articulated two primary theories of employment discrimination under Title VII of the 1964 Civil Rights Act (Title VII). ${ }^{1}$ The two theories can be analogized to two of the three prevalent doctrines of common law tort-intentional tort and strict liability. This article sets forth the basis, in current law and in social psychology, for a third theory of Title VII liability, analogous to the third major doctrine of tort lawthe doctrine of negligence. My purpose is both to demonstrate that much employment discrimination is the result of tortious acts that are most appropriately described as negligent, and to reveal that the existing law of employment discrimination, while eschewing the term negligence, frequently incorporates the doctrine.

Part I of this article examines psychological and sociological data on racism that demonstrate why discrimination is more closely analogous to negligent conduct than it is to intentional conduct. Drawing on the pioneering work of Charles Lawrence in The Id, the Ego, and Equal Protection: Reckoning with Unconscious Racism, ${ }^{2}$ recent studies support the assertion that most discrimination is not the result of malice, hatred, ill will, or bigotry: it is the result of unintended and unconscious stereotyping. Thus, a theory of discrimination liability that focuses on intentional wrongdoing will inevitably miss the mark; it will condemn only a small percentage of the wrongful conduct Title VII was enacted to eliminate.

† Visiting Associate Professor of Law, Golden Gate University; J.D., Harvard Law School (1978); B.A., University Without Walls/Berkeley (1972). I am extremely grateful to Stephen Bundy and Jan Vetter for their suggestions during the planning of this article; to Erwin Chemerinsky, Marjorie Heins, Herma Hill Kay, Mary Pat Treuthart, and Stephanie Wildman for their critiques of its several drafts; to my research assistants Rod Fliegel, Sheryl Hahn, Ghada Saliba and Linda Sullivan, and to my University of Pennsylvania Law Review editors, Wendy Beetlestone and Joseph Chan, for their invaluable assistance and dedication; and to my wife Marcy Kates for her editing, encouragement, patience, support and love.

142 U.S.C. $\$ \S 2000$ e to -17 (1988). Title VII prohibits employers of 15 or more persons from discrimination in employment on the basis of race, color, religion, sex, or national origin. See 42 U.S.C. $\$ \S 2000$ e(b), 2000e-2a (1988).

${ }^{2}$ Charles R. Lawrence III, The Id, the Ego, and Equal Protection: Reckoning with Unconscious Racism, 39 STAN. L. REV. 317 (1987). 
Part II examines the extent to which negligence doctrine is already reflected in the law of employment discrimination. Subpart A briefly traces the development of the two well recognized theories of employment discrimination law under Title VII-strict liability and intentional tort. Subpart B describes the existing incorporation of a negligence test, termed a "less discriminatory alternative" standard, as an alternative mode of proof within the strict liability theory. Subpart $\mathrm{C}$ describes the existing duty to accommodate religious differences, pregnancy, and physical and mental disabilities, ${ }^{3}$ which is re-examined as a form of negligence law. Subpart $D$ describes the development of an affirmative duty imposed on employers to prevent improper harassment of employees. The violation of that duty is analogous to liability for the failure to protect those with whom the actor has a "special relationship" under negligence law.

The conclusion sets forth a theory of negligent discrimination. It is proposed that an employer should be found liable under Title VII for negligent discrimination when the employer fails to take all reasonable steps to prevent discrimination that it knows or should know is occurring, or that it expects or should expect to occur. An employer should also be found liable when it fails to conform its conduct to the statutorily established standard of care by making employment decisions that have a discriminatory effect, without first carefully examining its processes, searching for less discriminatory alternatives, and examining its own motives for evidence of stereotyping.

\section{UNCONSCIOUS DISCRIMINATION}

\section{A. The Theory of Unconscious Racism is Applicable to the Problem of Employment Discrimination}

In Charles Lawrence's landmark article, The Id, the Ego, and Equal Protection: Reckoning with Unconscious Racism, ${ }^{5}$ Lawrence argues that:

${ }^{3}$ Employment discrimination on the basis of disability is prohibited under the recently enacted Americans with Disabilities Act of 1990, 42 U.S.C.A. $\S \S 12101-17$ (West pamphlet 1992).

${ }^{4}$ See, e.g., RESTATEMENT (SECOND) OF TORTS § 314B (1965) (providing that employers may be liable for failing to prevent harm to their employees).

${ }^{5}$ Lawrence, supra note 2. 
Traditional notions of intent do not reflect the fact that decisions about racial matters are influenced in large part by factors that can be characterized as neither intentional-in the sense that certain outcomes are self-consciously sought-nor unintentional-in the sense that the outcomes are random, fortuitous, and uninfluenced by the decisionmaker's beliefs, desires, and wishes. ${ }^{6}$

Rather, racist acts often appear to be the product of unconscious bias and stereotyping. Racist behavior, including employment discrimination, can in such cases be ascribed to the failure of decision-makers to reflect upon, and cleanse their decisions of, the unconscious bias underlying their decisions.

Lawrence analyzes racism as a mental illness, and invokes both the Freudian and cognitive schools of psychology to understand its nature. ${ }^{7}$ Applying a Freudian analysis, he contends that racism finds its source in the Id, the unconscious, and is largely inhibited by the Ego. ${ }^{8}$ As long as the Ego is in control, people behave in socially acceptable ways. With regard to race, this means that overtly racist behavior is avoided; it is suppressed. But racism may find its way into expression through "Freudian slips," such as the use of a racial slur when it escapes Ego censorship. ${ }^{9}$ Or it may remain completely out of view, yet nonetheless influence behavior. ${ }^{10}$

Examining racism through a cognitive analysis, Lawrence explains that a part of a person's attempt to understand his or her relationship to the world relies on categorizing other individuals. ${ }^{11}$ This coping mechanism of categorization, when applied to race, results in racial misconceptions and other stereotypes. ${ }^{12}$ The process tends to correlate certain groups with certain propensities; for example, associating human intelligence, or the propensity to violence with a particular category of people. ${ }^{13}$ "Thus, through personal and cultural experience the individual comes to associate characteristics such as 'intelligence,' 'laziness,' 'honesty,' or

${ }^{6} I d$. at 322 (footnote omitted).

${ }^{7}$ See id. at 322-23.

${ }^{8}$ See Lawrence, supra note 2, at 331-32.

${ }^{9}$ See id. at 339-40.

${ }^{10} \mathrm{See} i d$. at 335.

11 See id. at 337.

12 See id.

13 See id.; see also infra notes $42-53$ and accompanying text (discussing the NORC studies and racial stereotyping in the United States). 
'dirtiness' with classifications of people."14 Since our "categorization" of people is learned and experienced at a very young age, we may not be conscious of having internalized those feelings and beliefs. ${ }^{15}$

Applying Lawrence's theory to employment discrimination, employers who do not consciously hold racist views, but who nonetheless discriminate in their conduct, may be viewed in Freudian terms as having suppressed their racism, so that it operates on their unconscious. In cognitive terms, employers may be seen as having internalized their racism, so that it affects their decision making without their actual knowledge. Viewed either way, if, as asserted herein, experimental psychology reveals that unconscious racism governs behavior among white employers who would not consciously choose to discriminate against African Americans, ${ }^{16}$ then their conduct cannot be explained by a search for malice or bigotry. If those whites charged with making employment decisions have internalized negative stereotypes about African Americans, as the experimental data suggest, the stereotypes will be reflected in their decisions, even if they have no desire, motivation or intent to treat African Americans differently. Such unconscious discrimination, if prevalent, will have substantial social and legal consequences.

\section{B. Social Science Data Support the Theory of Unconscious Racism and Demonstrate Why Employment Discrimination is Frequently the Result of Negligent Conduct}

The theory that racial discrimination is frequently the result of negligent, as opposed to intentional, behavior, finds considerable support in the work of social psychologists and sociologists. ${ }^{17}$

14 Lawrence, supra note 2, at 338-39.

15 See id. at 337-38.

${ }^{16}$ I use the terms "African American" and "black" interchangably, reflecting the current common usage of both terms throughout the English language, and particularly in the African American community.

${ }^{17}$ I have focused here on the data concerning race discrimination, but the same point could be made regarding other forms of unlawful discrimination. In the area of sex discrimination, for example, extensive data support the conclusion that sexbased stereotyping and unconscious sexism are pervasive in American society. See Mary F. Radford, Sex Stereolyping and the Promotion of Women to Positions of Power, 41 HASTINGS L.J. 471, 486-503 (1990) (discussing how sex stereotypes effect employee evaluations); Deborah L. Rhode, The "No-Problem" Problem: Feminist Challenges and Cultural Change, 100 YALE L.J. 1731, 1764-68 (1991) (discussing more recent studies establishing unconscious sexism); Nadine Taub, Keeping Women in Their Place: 
Surveys taken over the past fifty years demonstrate that views expressed by whites about racial discrimination in employment have dramatically changed, and that virtually all whites in American society now profess a commitment to nondiscrimination in employment. If our society mirrored the views expressed by its white members, Title VII and other statutory prohibitions of race discrimination in employment would be unnecessary. But the surveys, when more closely examined, demonstrate a consistently high level of general racial prejudice held by whites against African Americans. Although the surveys show that the percentage of whites openly supporting discrimination against African Americans has dropped considerably, surveys on the implementation of civil rights, and more sophisticated surveys attempting to measure white stereotypes about African Americans, demonstrate extremely high levels of covert racism. These surveys support the view that overt racism has lost favor socially, but racist attitudes lie close beneath the surface of our society. ${ }^{18}$

Field and laboratory experiments support the conclusions of the more sophisticated surveys, which attempt to measure stereotyping, over those that measure overt racism; the level of racist behavior observable in these controlled experiments is disturbingly high. Similarly, recent attempts to test directly for racial discrimination in employment, using controlled field experiments, also yield high levels of discrimination. ${ }^{19}$ Given the wide variance between expressions of overt racist principles and evidence of racist behavior, it appears either that huge numbers of whites are falsely denying their consciously held racist beliefs, or that many acts of racist behavior are motivated by unconscious, rather than intentional, racism. If much white racist behavior is unconscious, a theory

Stereotyping Per Se as a Form of Employment Discrimination, 21 B.C. L. REV. 345, 349-61 (1980) (discussing social science data from economists, sociologists, and social psychologists). Similarly, the 1990 NORC study, infra notes $46-53$ and accompanying text, found that whites held negative stereotypes about Asian Americans, Hispanic Americans, and Jews, as well as African Americans. While there is a risk of minimizing race discrimination against African Americans by analogizing it to other forms of discrimination, see Trina Grillo \& Stephanie M. Wildman, Obscuring the Importance of Race: The Implication of Making Comparisons Between Racism and Sexism (or Other-isms), 1991 DUKE L.J. 397, 399-411, the data suggest that the phenomenon of negligent discrimination applies to all categorical discrimination prohibited by Title VII and related nondiscrimination statutes.

${ }^{18}$ See infra notes $20-59$ and accompanying text.

${ }^{19}$ See infra notes 76-84. 
that tests only for intentional discrimination necessarily misses its mark much of the time.

\section{National Polling on Racial Attitudes of Whites}

Three national survey organizations have been conducting regular polls on the racial attitudes and beliefs of white adults over the past five decades: the National Opinion Research Center (NORC) at the University of Chicago, the Institute for Social Research (ISR) at the University of Michigan, and the Gallup Organization, the American Institute of Public Opinion (AIPO or Gallup). A recent comprehensive study by Howard Schuman, Charlotte Steeh, and Lawrence Bobo examines the trends exhibited by these polls during the period 1942 through $1987 . .^{20}$ The data reported in the study support the conclusion that at the level of consciously held attitudes about African Americans, there has been considerable progress in whites' statements of principle regarding purely public civil rights, such as employment and public accommodations discrimination. These principles, however, are not expressed as strongly in areas of private life, such as marriage and housing, and are in conflict with those views expressed about support for civil rights enforcement. ${ }^{21}$

In response to questions about the principle of nondiscrimination in employment, the white response indicates that overt discrimination has lost all social acceptance. In 1944, only $45 \%$ of the white adult NORC respondents agreed that "Negroes should have as good a chance as white people to get any kind of job"; $55 \%$ instead stated that "white people should have the first chance."22 By 1963, the year before Title VII was enacted, the percentage favoring equal opportunity had risen to $85 \%$, and when last asked in 1972, seven years after Title VII took effect, the number in support of job equality had risen to a nearly unanimous $97 \% .{ }^{23}$ If those $97 \%$ of the adult white population who believe, or profess to believe, in equal employment opportunity acted in conformance with their beliefs, the problem of race discrimination in employ-

20 See Howard Schuman Et al., Racial AtTtTUdes IN AMERICA: Trends AND INTERPRETATIONS 71-138 (1988).

${ }^{21}$ See infra notes $22-45$ and accompanying text.

${ }^{22}$ SCHUMAN ET AL., supra note 20, at $74-75$ tbl. 3.1. Schuman reduced all of the percentages to pro and con equaling $100 \%$, by eliminating the undecided or nonresponsive, except as otherwise noted. See id. at 73-77.

${ }^{23}$ See id. at 74-75 tbl. 3.1. The question was not asked after 1972. See id. 
ment would largely disappear. But other survey results, and experiment results, reveal a wide gap between the $97 \%$ supporting nondiscrimination in principle and the number of whites refraining from discrimination.

First, support for the principle of nondiscrimination in employment does not translate into support for federal enforcement of employment discrimination laws. An ISR question asking whether "the government in Washington [should] see to it that black people get fair treatment in jobs or leave these matters to the states and local communities" 24 found only $38 \%$ supporting federal enforcement in 1964. By 1974, the number had declined to $36 \%{ }^{25}$ By 1986, the number had declined even further, to $33 \%$, with another $33 \%$ stating that they had no interest in the issue and a plurality of $34 \%$ stating that the federal government should not get involved. ${ }^{26}$

This difference between white support for the principle of equal opportunity and white support for federal enforcement of black employment rights is dramatic. It suggests that the $97 \%$ support in principle is an empty gesture; that true white support for equal employment opportunity is far lower. One could theorize, however, that the difference merely reflects fiscal concerns, or a preference for local enforcement of civil rights over federal intervention. The survey results on equal opportunities in housing, however, suggest that the difference is not fiscal or procedural, but substantive; a substantial number of whites are willing to lend abstract support to civil rights principles, but are opposed to seeing those principles carried out.

A disparity similar to that in employment opportunity, albeit with substantial support for segregation still extant, was found in the area of open housing. Forty percent of the NORC respondents in 1963 strongly agreed that "[w]hite people have a right to keep blacks out of their neighborhoods if they want to, and blacks should respect that right," and another 21\% slightly agreed. ${ }^{27}$ By 1987 the number of strong supporters had dropped to $10 \%$, while another $16 \%$ still slightly agreed. ${ }^{28}$ In and of itself, $26 \%$ support for permitting housing discrimination is strikingly high, but even

24 Id. at 88-91 tbl. 3.2 \& fig. 3.4.

${ }^{25}$ See id.

${ }^{26}$ See id. at xii (providing additional data on trends in white attitude from 19841987).

${ }^{27}$ Id. at $74-75$ tbl. 3.1 .

${ }^{28}$ See id. at xii. 
more dramatic is the fact that many who do not support such discrimination are nonetheless unwilling to outlaw it. In six NORC surveys between 1973 and 1983, a significant (if declining) majority, ranging from $66 \%$ in 1973 to $54 \%$ in 1983 have supported a hypothetical law providing "that a homeowner can decide for himself who to sell his house to, even if he prefers not to sell to blacks" over a law providing "that a homeowner cannot refuse to sell to someone because of their race or color." ${ }^{29}$ In 1984, the number supporting an open housing law first reached $50 \%$, dropping again in 1986 and rising back to $50 \%$ in $1987 .^{30}$

Since government enforcement of the law was not an issue in these survey questions, the fiscal or states' rights explanations cannot explain the disparity between support for equality and support for outlawing discrimination. The 50\% opposition is not opposition to government intervention; it is opposition to the existence of a legal right to open housing. Moreover, a third series of surveys on housing discrimination further demonstrates that this opposition to open housing laws is substantive. Asked by ISR in face-to-face interviews whether they would "personally prefer to live in a neighborhood that is all white, mostly whites, mostly blacks, mixed, [or if it made] no difference," ${ }^{31}$ in $197640 \%$ of the white respondents preferred an all white neighborhood, while $32 \%$ preferred a mostly white neighborhood and only $28 \%$ preferred a mixed neighborhood or felt it made no difference. ${ }^{32}$ It should be apparent that "all white" neighborhoods cannot continue to exist if open housing laws are enforced. Here again, the variance between support of a civil rights principle and support for its implementation is substantial, and even the level of support for implementation does not reflect the general personal preference of whites to remain largely segregated from African Americans.

Turning to public accommodations, the response to the NORC question asking whether people "think there should be separate sections for Negroes in streetcars and buses"33 again showed high support for nondiscrimination principles, with support dropping by $42 \%$ between 1942 and 1970 , although still standing at $12 \% .^{34}$

\footnotetext{
${ }^{29}$ Id. at 88-89 tbl. 3.2 .

${ }^{30} \mathrm{See}$ id. at xii.

31 Id. at 67 tbl. 2.3.

${ }^{32}$ See id. at 66-67, 106-08 tbl. 3.3, 111-13.

${ }^{33} \mathrm{Id}$. at 74 .

${ }^{34}$ See id. at 74-75 tbl. 3.1.
} 
Here again, the $88 \%$ support for integration of transportation did not translate into support for civil rights enforcement, at least in the related area of restaurant and hotel integration. When ISR informed its subjects in 1974 that such integration was required by law, and then asked if "the government should support the right of black people to go to any hotel or restaurant they can afford, or should it stay out of this matter, ${ }^{\prime 85} 20 \%$ replied that the government should not enforce the law, and another $14 \%$ replied they were uninterested in whether the law was enforced or not; only $66 \%$ favored enforcement. ${ }^{36}$

In more private areas, even civil rights principles divorced from government enforcement find substantial white resistance. In the area of intermarriage, as late as $1982,34 \%$ of the NORC respondents favored laws prohibiting racial intermarriage. That is, one in three white adult Americans not only believed that marriage between blacks and whites is wrong, but further believed that it should be illegal. And while such laws carried 62\% support in 1963, the support had dropped to $29 \%$ in 1977 before rebounding in 1980 and 1982 to $32 \%$ and $34 \%$ respectively. ${ }^{37}$ By the most recent survey in $1987,27 \%$ still supported anti-miscegenation laws. ${ }^{38}$

The findings were similar in response to the question "[a]re you in favor of desegregation, strict segregation, or something in between?"39 Given the opportunity to support something other than desegregation without supporting strict segregation, a full $60 \%$ of white adult ISR respondents favored the "in between" category in 1978. ${ }^{40}$ Although the number favoring strict segregation slipped from $25 \%$ in 1964 to $5 \%$ in 1978 , only $35 \%$ of the 1978 respondents favored desegregation. ${ }^{41}$

A few surveys, most notably a series of questions asked by NORC between 1942 and 1968, attempted to understand the source of white racism by measuring white stereotypes about African Americans. ${ }^{42}$ Beginning in 1942, NORC asked, "[i]n general, do

95 Id. at 90.

${ }^{36}$ See id. at 88-90 tbl. 3.2.

${ }^{37}$ See id. at 74-76 tbl. 3.1.

${ }^{38}$ See id. at xii.

${ }^{39} \mathrm{Id}$.

${ }^{40}$ See id.

${ }^{41}$ See id.

42 Important work in this area was done in the 1940s and 1950s by Gordon Allport of Harvard. See Gordon W. AllPORT, THE NATURE OF PREJudice 196-99 (1954) (noting that there exists a greater degree of consensus in the stereotypes ascribed to African Americans than for any other group). 
you think Negroes are as intelligent as white people-that is, can they learn things just as well if they are given the same education and training?" 43 In 1942, 53\% answered that African Americans were not as intelligent as whites. ${ }^{44}$ By 1968, the number had declined to a still very sizable $23 \% .{ }^{45}$ But here again, $77 \%$ of the whites who believed African Americans are as intelligent as whites may be overstated, because the response that African Americans are less intelligent may be recognized as now socially unacceptable even among those whites who continue to believe it to be true.

A 1990 NORC study, conducted after the Schuman study was published, sheds further light on racial attitudes of whites toward African Americans in the area of intelligence and a number of other topics in which stereotypes abound. ${ }^{46}$ In the 1990 NORC study, white subjects were asked to rate various ethnic groups ${ }^{47}$ regarding certain character traits, such as unintelligent/intelligent, hard working/lazy, patriotic/unpatriotic, and violence-prone/not violence-prone. The subjects were given a scale of one to seven, and asked to place each ethnic group rated on the appropriate point of the scale for each characteristic. Unlike the earlier polls reported by the Schuman study, the 1990 NORC study carefully avoided using declarative statements with which the subjects could agree or disagree, thereby reducing the likelihood that the subjects would censor themselves from stating socially unacceptable views. For example, subjects were not asked the 1942-68 question "do you think Negroes are as intelligent as white people?" ${ }^{48}$; they instead were asked to generally rate whites in intelligence, and then to do the same for blacks. ${ }^{49}$

Four of the resulting comparisons are illustrative of the depth and depravity of racial stereotyping in America today. Asked to rate blacks and whites on the characteristic of intelligence, $53.2 \%$ of the subjects rated African Americans less intelligent, with $40.5 \%$ stating no difference. ${ }^{50}$ On the question of hard working/lazy, $62.2 \%$ of

${ }^{43}$ SCHUMAN ET AL., supra note 20 , at $118-19$ tbl. 3.4 .

44 See id.

${ }^{45}$ See id.

${ }^{46}$ See TOM W. SMITH, NATIONAL OPINION RESEARCH CTR., ETHNIC IMAGES, GENERAL SOCIAL SURVEY TOPICAL REPORT No. 19 (1990) [hereinafter 1990 NORC STUDY] (examining the images whites have of various ethnic groups).

47 The groups were: Whites, Jews, Blacks, Asian Americans, Hispanic Americans, and Southern Whites. See id. at 2.

${ }^{48}$ SCHUMAN ET AL., supra note 20 , at 118 tbl. 3.4 .

49 See id. at $2-4$.

${ }^{50}$ See id. at 9 tbl. 1. 
the subjects rated African Americans as less hard working than whites, while $31.9 \%$ rated them equally. ${ }^{51}$ Fifty six point one percent rated African Americans as more violence prone, with $30 \%$ rating no difference. ${ }^{52}$ Fifty point six percent rated African Americans as less patriotic than whites, and $46.6 \%$ rated them equally patriotic. ${ }^{53}$ The high numbers of whites who view African Americans as less intelligent and less hard working than whites have particular significance for the issue of employment discrimination, since it is likely that employers selecting employees will choose those they view as the most intelligent and hard working. In addition, in matters of employee evaluation, stereotypes may become self-fulfilling prophesies by way of suggestion; in other words, all persons are prone to see what they expect to see. An employer is thus likely, at the $97 \%$ level, to subscribe to a belief in the principle of equal employment opportunity, and to articulate that belief, yet is nonetheless more likely than not to view black employees and applicants as less intelligent and hard working than white employees and applicants.

This problem of stereotypes creating self-fulfilling prophesies is well illustrated by an experiment conducted by Allport and Postman in the 1940s. Allport and Postman showed a drawing to over forty groups of subjects, depicting a subway train in which a black man and $a$ white man are standing together talking. The black man is dressed in business clothes; the white man is wearing a $\mathrm{T}$-shirt and carrying a straight razor. The subject was asked to view the picture briefly, and describe it to a second subject, who described it to a third, as in the children's game "telephone." After description through a chain of six or seven subjects, the drawing was more often than not described as one in which a black man was holding a razor. Often he was using it to threaten the white man. ${ }^{54}$

Although the 1990 NORC survey, and earlier surveys on implementation of civil rights laws, disclose an extremely high level of white racism, one obvious problem with survey data is the risk

51 See id.

52 See id.

53 See id.

54 See Gordon W. Allport \& Leo Postman, The Psychology of Rumor 111 (1947) (relating the experiment and describing it as an example "of the impact of cultural expectations on perception"); see also ELIZABETH F. LOFTUS, EYEWITNESS TEstimoNy, 38-39 (1979) ("In over half of the experiments . . . the [black] man ... is said to hold the razor ... [sometimes] reported as brandishing it ... or as threatening the white man with it."). 
that the respondents are not being truthful in their answers. As high as the numbers are, the disparity between the questions on principle and those on implementation suggests that survey results generally may underestimate the true level of white racism because of the concern by respondents not to appear racist. If overt racism is socially unacceptable behavior, persons being surveyed, even anonymously, may be reluctant to reveal their true beliefs. This is borne out by a series of experiments conducted in the 1970s in which white subjects were polled regarding their views on African Americans, with half hooked up to a device (a "bogus pipeline") that was described as a sophisticated lie detector. ${ }^{55}$ The subjects attached to the bogus pipeline admitted holding far more negative stereotypes than did those merely asked to rate racial characteristics. For example, Sigall and Page describe the subjects hooked up to the device as describing African Americans as less "honest" and "intelligent" and more "lazy," "stupid," and "physically dirty" than did those subjects not hooked up to the bogus pipeline. ${ }^{56}$ (Both groups of whites, those hooked up and those not hooked up to the machine, rated African Americans negatively as compared to whites. $)^{57}$ Allen demonstrated that whites who had been rated as "unprejudiced" in a paper test on racial attitudes showed a significant reduction of expressed admiration of black public figures when hooked up to the bogus pipeline. ${ }^{58}$ Carver's study is particularly relevant to employment discrimination. The subjects were asked to characterize a fellow student based on a transcript of an

55 See Harold Sigall \& Richard Page, Current Stereotypes: A Little Fading, A Little Faking, 18 J. PERSONALITY \& SOC. PSYCHOL. 247, 250-54 (1971) (reporting that respondents hooked up to the bogus pipeline were more likely to assign negative stereotypes to African Americans); see also Bem P. Allen, Social Distance and Admiration Reactions of "Unprejudiced" Whites, 43 J. PERSONALITY \&c SOC. PsYCHOL. 709, $717-23$ (1975) (describing the methodology and results of the bogus pipeline studies); Charles S. Carver et al., Favorable Evaluations of Blacks and the Handicapped: Positive Prejudice, Unconscious Denial, or Social Desirability?, 8 J. APPLIED SOC. PSYCHOL. 97,99 (1978) (using the bogus pipeline technique to test reactions to African Americans and to the handicapped); Faye Crosby et al., Recent Unobtrusive Studies of Black and White Discrimination and Prejudice: A Literature Review, 87 PsYCHOL. BuLl. 546, 559 (1980) (describing the studies and discussing the major findings of the bogus pipeline results).

${ }^{56}$ See Sigall \& Page, supra note 55, at 250-51.

${ }^{57}$ See id.

58 See Allen, supra note 55, at 717-23 tbl. 4 ("Experiment IV"). In a paper and pencil test, the "unprejudiced" whites rated the black public figures higher than a matched set of white public figures. Once hooked to the machine, they rated the white public figures higher than the black public figures. 
interview. The transcripts were identical, save that half identified the interviewee as African American. Those not hooked up to the bogus pipeline actually gave the black student a higher rating than the student whose race was not identified, but those persuaded by the operation of the machine that their "true feelings" were being measured, rated the black student significantly lower than the other. ${ }^{59}$ These results suggest a high level of dissembling by many survey participants, and raise the question of whether even the data revealed in the more subtle 1990 NORC survey understate the true level of white racism.

\section{Unobtrusive Studies of Racial Attitudes of Whites}

One response to the limitations of survey data has been to design experiments that measure behavior, rather than attitude. Such tests can both ferret out conscious racism which the subject would prefer not to admit-as in the bogus pipeline experimentsand reveal unconscious racism, which may be unknown to the subject. In 1980, Crosby, Bromley, and Saxe examined a large number ${ }^{60}$ of field experiments conducted since the mid-1960s which attempted to test for the presence of racism by testing for the presence of discriminatory behavior. These experiments attempt to observe white subjects in an interracial situation where their conduct, if uninfluenced by racism, would be expected to be similar to their conduct with other whites. The results present strong evidence that the reduction in racist views expressed in surveys does not foretell a corresponding reduction in racist behavior.

Thirty of the studies reviewed by Crosby were "helping behavior studies" in which white subjects were faced with people (half of whom were white, half of whom were black) posing as needing assistance. For example, in a number of studies a person posing as a shopper would appear to drop a bag of groceries; the study measured whether white passers-by were more likely to help if the person in need was white or black. ${ }^{61}$ In other studies, a person

${ }^{59}$ See Carver, supra note 55, at 101-03.

${ }^{60}$ Crosby selected 46 such studies which utilized "unobtrusive" experimentsexperiments in which subjects are not aware that they are being studied, or not aware that the study is examining the subject of discrimination. Crosby, supra note 55, at 546-47.

61 See, e.g., Lauren G. Wispe \& Harold B. Freshley, Race, Sex, and Sympathetic Helping Behavior: The Broken Bag Caper, 17 J. PERSONALITY \& SOC. PsYCHOL. 59, 62-65 (1971) (measuring differences in the helping behavior of men and women and finding that "there were no significant differences between blacks and whites in help given 
would pose as a motorist in distress to measure whether white drivers were more likely to help blacks or whites. ${ }^{62}$ In Crosby's analysis of these thirty experiments, she found that in $40 \%$ of the studies, white subjects showed discriminatory behavior against blacks. ${ }^{63}$

High as it is, this $40 \%$ measure of discrimination may be understated due to the social scientists' conservative analysis of what constitutes nondiscrimination. For example, Wispe concluded that the white subjects showed no discrimination in their willingness to help the shoppers whose bags broke. ${ }^{64}$ However, in her analysis of the Wispe shopping bag experiment, Crosby notes, while whites and blacks were offered assistance in equal numbers, the amount of assistance offered was not equal. ${ }^{65}$ Rather, $63 \%$ of the time that white subjects were aiding white women, the subjects gave complete help, picking up all of the groceries. But $70 \%$ of the time white subjects helped black women, they gave only perfunctory help, picking up only a few packages. ${ }^{66}$ When complete help and perfunctory help are distinguished, Wispe's study, which concludes that there was no showing of racial differences in helping behavior, demonstrates that whites are exactly twice as likely to help other whites as they are African Americans. ${ }^{67}$

In most of the helping behavior studies analyzed by Crosby, the subject was engaged in a face to face encounter with the person needing help. But in eight of the thirty studies, the encounter was remote, generally by telephone. In comparing the face to face experiments with the remote experiments, Crosby found that in $32 \%$ of the face to face studies there was white discrimination against blacks, while in $75 \%$ of the remote studies there was such

or received"). Crosby, however, noted that Wispe's analysis of the shopping bag experiment did not measure the amount of help received by whites and blacks. Crosby found that the amount of assistance offered to blacks and whites was significantly different. See Crosby, supra note 55, at 549; infra notes 64-67 and accompanying text.

62 See, e.g., Stephen G. West et al., Helping a Motorist in Distress: The Effects of Sex; Race and Neighborhood, 31 J. PERSONALITY \& SOC. PsYCHOL. 691, 693-94 (1975) (describing the method of their emergency motorist study and finding that the subjects were helped primarily by people of their own race).

${ }^{63}$ See Crosby, supra note 55, at 549, 550-52 tbl. 1.

${ }^{64}$ See Wispe, supra note 61 , at 64-65.

${ }^{65}$ See Crosby, supra note 55, at 549 .

${ }^{66}$ See Wispe, supra note 61, at 62 tbl. 1; see also Thomas F. Pettigrew, New Patterns of Racism: The Different Worlds of 1984 and 1964, 37 RUTGERS L. REV. 673, 688-89 (1985).

${ }^{67}$ See Wispe, supra note 61 , at 62 tbl. 1 (white subject/positive help). 
discrimination. ${ }^{68}$ This disparity supports the view that when engaging in public activity, whites may be more careful to avoid discriminating, but when acting privately or anonymously, many whites will discriminate against African Americans. One particular study which supports this analysis was especially striking. An envelope containing a completed graduate school application was left at an airport phone booth. The application contained a stamped, addressed envelope for submission to the graduate school, a note to "Dad" asking him to please mail the application, and, as part of the application, a photograph of the candidate. White adults were observed picking up the application in the phone booth and inspecting it. They were found to be significantly more likely to mail the application when the applicant was white than when the applicant was black. ${ }^{69}$ Crosby theorized that white helping behavior was more prevalent in face to face encounters because "whites today hold prejudiced attitudes but that they inhibit expression of this prejudice when the possibility of negative consequences is great. In the more removed and anonymous situations (Type 2), discrimination is much more likely to emerge. "70

In addition to the helping behavior studies, another set of studies examined by Crosby measured nonverbal behavior to test for racism. Each of the four experiments in this group found measurable white racism. ${ }^{71}$ For example, in one experiment white male students at Princeton were asked to interview a white or black high school student. ${ }^{72}$ The interviewees were trained participants (confederates), instructed to behave in a like fashion. As Crosby reports "the subjects sat further away from the black confederates than from the white confederates, made more speech errors when talking to the blacks than when talking to the whites, and terminated the black interviews sooner than the white interviews. In short, a marked degree of nonverbal discriminatory behavior was obtained." 73

${ }^{68}$ See Crosby, supra note 55, at 549, 559 tbl. 2.

${ }^{69}$ See Peter L. Benson et al., Pretty Pleases: The Effects of Physical Attractiveness, Race, and Sex on Receiving Help, 12 J. EXPERIMENTAL SOC. PSYCHOL. 409, 413-14 (1976).

${ }^{70}$ Crosby, supra note 55, at 549.

${ }^{71}$ See id. at 555-56.

72 See Carl O. Word et al., The Nonverbal Mediation of Self-Fulfilling Prophecies in Interracial Interaction, $10 \mathrm{~J}$. EXPERIMENTAL SOC. PSYCHOL. 109, 112-15 (1974).

${ }^{73}$ Crosby, supra note 55, at 555. 
A laboratory study from 1976 demonstrated the impact of racial stereotyping on perception. ${ }^{74}$ White undergraduates viewed a videotape on a monitor in which one participant shoved another. When the person doing the shoving was black, the subjects described the shove as violent, but when the person doing the shoving was white, it was described as harmless "playing around. ${ }^{n 75}$

\section{Experimental Field Tests Of Employment Discrimination}

In one recent experiment, a direct measure of race discrimination in employment was obtained. The test, conducted by the Urban Institute, used white and black job-seekers to measure the difference in treatment of qualified employment candidates by employers advertising for employees. ${ }^{76}$ The Urban Institute study carefully matched the employment-related characteristics of ten pairs of young men. In each pair, one man was black, one was white. Each applied for entry-level jobs advertised in newspapers in Washington, D.C. and Chicago during the summer of 1990. A total of 476 tests, termed "audits," were conducted. The study found that in $15 \%$ of the audits the white job-seeker was offered a job while his black counterpart was not; in $5 \%$ of the tests the black job-seeker was favored. ${ }^{77}$ In our nation's capitol, whites were favored with job offers $19 \%$ of the time, African Americans $6 \%{ }^{78}$ Thus, overall, a white job-seeker was substantially more likely to be offered entry level employment than an equally qualified black job-seeker. Moreover, in $20 \%$ of the audits, the white job-seeker progressed further in the hiring process than his black counterpart; in $7 \%$, the black job-seeker progressed further. ${ }^{79}$ Thus, even where there was ultimately no job offer, there was significant discrimination against the black applicant. And, whites were positively "steered," directed

${ }^{74}$ See Birt L. Duncan, Differential Social Perceptions and Attribution of Intergroup Violence: Testing the Lower Limits of Stereotyping of Blacks, 34 J. PERSONALITY \& SOC. PSYCHOL. 590, 590-94 (1976).

75 See Crosby, supra note 55, at 556; supra text accompanying note 54.

${ }^{76}$ See MARGERY A. TURNER ET AL., OPPORTUNITIES DENIED, OPPORTUNITIES Diminished: RACIAL Discrimination IN Hiring (1991). An earlier study by the Urban Institute testing for employment discrimination against Hispanics reported similar results. See HARRY CROSS ET AL., EMPLOYER HIRING PRACTICES: DifFERENTIAL TREATMENT OF HISPANIC AND ANGLO JOB SEEKERS 61 (1990) (finding that "Hispanics ... face considerable barriers compared to their Anglo counterparts in obtaining interviews and offers of employment for low-skilled, entry-level jobs").

77 See TURNER, supra note 76, at 39 tbl. 4.2.

${ }^{78}$ See id. at 41 tbl. 4.4.

${ }^{79}$ See id. at 39 tbl. 4.1 . 
to better paying jobs, $5 \%$ of the time, while African Americans were steered $3 \%$ of the time. ${ }^{80}$

Although the Urban Institute auditors were instructed to push forward with their applications unless or until they were either offered or denied the job, many job-seekers will be discouraged from pursuing an employment application by their treatment in the hiring process. It is thus significant that in $8 \%$ of the Washington, D.C. audits, the black auditor was given greater discouragement from applying than was his white counterpart, while in another $6 \%$ of the audits, the white auditor was given greater encouragement. ${ }^{81}$ For those $45 \%$ of the audits where both auditors received interviews, in $50 \%$ of the interviews, the white auditor was favored compared to the black auditor in waiting time, length of interview, number of interviewers, positive comments, or negative comments; in $27 \%$, the black auditor was favored. ${ }^{82}$ For example, "a black auditor reported that he had received a very discouraging impression of the job, including the statement that 'your supervisor will work your butt off.' The white partner, on the other hand, was told that the company offered great opportunities for advancement. ${ }^{883}$ The discriminatory results were not uniform across all job categories. In general, African Americans were more likely to encounter unfavorable treatment in higher paying, higher status jobs and in jobs involving substantial customer contact. ${ }^{84}$

\section{The Problem of Unconscious Racism Demands the Solution of Negligence Liability for Unconscious Employment Discrimination}

Comparing the experimental data to the survey results on racism yields a number of conclusions. From the surveys alone, it is clear that while few whites admit to holding overtly racist principles, particularly in the area of equal employment opportunity, racism remains a potent force in white attitudes about African Americans. When surveys are designed to reduce the phenomenon of false negatives from participants reluctant to admit their racist beliefs, the level of white racism that emerges is even higher. ${ }^{85}$ And when

${ }^{80}$ See id. at 43 tbl. 4.5 .

81 See id. at 45-46 tbl. 4.6. Notably, in Chicago the black auditors were favored over their white counterparts and given more encouragement $5 \%$ of the time.

82 See id. at $45-48$ tbl. 4.7 .

${ }^{83} \mathrm{Id}$. at $48-49$.

84 See id. at 52-53.

${ }^{85}$ See supra notes 55-59 and accompanying text. 
experiments test for observed racist behavior, the results are higher than even these more sophisticated survey results would predict. ${ }^{86}$ One possible explanation is that survey participants are dissembling at a very high level. This explanation, if true, is itself highly significant in examining the problem of employment discrimination litigation: if whites routinely lie in order to avoid admitting holding racist views, then white testimony regarding the reasons for employment decisions ought to be subjected to a high degree of skepticism. Another explanation, however, far more compatible with the experimental data, is particularly relevant to a theory of negligent discrimination. This explanation is that whites are frequently simply unaware of their own racism.

If whites are frequently unaware of their own racism, a theory of employment discrimination that focuses on an intent to discriminate provides no remedy for most discrimination. Yet the victims of unconscious discrimination have suffered the same economic damages, and often the same emotional damages, as the victims of knowing bigotry. The nature of the wrong committed by the employer who decides not to hire.African Americans, or women, or members of ethnic or religious minority groups, because of a selfacknowledged prejudice, may be greater than that of the employer who is merely unaware of his own propensities, but the harm caused by the unconscious discrimination is largely the same. Intentional, bigoted decisions may be appropriately the subject not only of compensatory but of punitive damages as well, and thus properly distinguished. But the primary problem of employment discrimination should be focused on determining liability, and assessing proper damages, where most discrimination occurs, at the level of unconscious discrimination.

Our understanding of Title VII's prohibition of employment discrimination should thus include a view of employment discrimination that distinguishes those cases involving intentional discrimination from those involving unconscious discrimination. Distinguishing between conscious and unconscious discrimination will help employees and employers alike. Employees would be able to prove liability where racism or other prohibited factors have played a substantial role in an adverse employment decision, whether or not the employer was cognizant of his motives. Employers would be

${ }^{86}$ See supra Part I.B.2-B.3. 
able to avoid the social stigma of a finding of discrimination where they intended no harm.

A system in which discrimination is analyzed under a theory of strict liability or intentional tort, rather than negligence, leaves little room for recognition of unconscious discrimination. Although Supreme Court decisions analyzing Title VII purport to endorse only the strict liability and intentional tort theories, a close examination reveals substantial support for a theory of negligent discrimination.

\section{THE SUPREME COURT'S ANALYSIS OF EMPLOYMENT}

DISCRIMINATION INCORPORATES NEGLIGENCE ANALYSIS AND INVITES THE DEVELOPMENT OF AN INDEPENDENT THEORY OF NEGLIGENT DISCRIMINATION

Few commentators have discussed Title VII as creating a tort action, ${ }^{87}$ and the two Supreme Court decisions in which the question has been addressed have been rendered obsolete by the Civil Rights Act of $1991 .^{88}$ In Curtis $v$. Loether, ${ }^{89}$ the Court considered the availability of jury trials in housing discrimination cases brought under another civil rights law, Title VIII of the Civil Rights Act of $1968 .^{90}$ It found that because Title VIII provided for actual and punitive damages, it created a cause of action analogous to a common law tort action. The Court contrasted the remedies available under Title VIII with those available under Title VII, noting that Title VII remedies were limited to back pay and other equitable relief. ${ }^{91}$ Title VII remedies, the Court reasoned, were not the kind of damages which constituted legal, as opposed to equitable, relief. Thus, with reference to the difference in the nature of the available damages, Title VIII was construed as creating a tort cause of action with a jury trial available. The Court did not reach the question of whether Title VII permitted a jury trial, but suggested by its reasoning that it did not because it was insufficiently tort-like.

${ }^{87}$ Such a discussion is, however, set forth in some detail, and criticized in Alfred W. Blumrosen, Strangers in Paradise: Griggs v. Duke Power Co. and the Concept of Employment Discrimination, 71 MICH. L. REV. 59, 100-06 (1972), and more recently in Cass R. Sunstein, Three Civil Rights Fallacies, 79 CAL. L. REv. 751, 761-65 (1991). 2000e).

${ }^{88}$ Pub. L. No. 102-166, 105 Stat. 1071 (1991) (amending 42 U.S.C. \$§ 1981,

89415 U.S. 189 (1974).

9042 U.S.C. $\$ 3601$ (1988).

${ }^{91}$ See Curtis, 415 U.S. at 196-97. 
The damages distinction between Title VII and Title VIII was erased with the passage of the Civil Rights Act of $1991 .^{92}$ Under the new Act, plaintiffs may be awarded unlimited actual and punitive damages in race discrimination cases, and up to $\$ 300,000$ in sex discrimination cases. ${ }^{93}$ The implications of this change were noted by the Court in its recent decision in United States $v$. Burke. ${ }^{94}$ Burke concerned the question of whether a settlement or award in a Title VII case was excludable from gross income under the Tax Code's exclusion for personal injury awards. The Court concluded that the decisive question was whether Title VII created a cause of action in tort or in contract, because damages in employment contract cases constitute taxable income while tort damages are excludable. The Court determined that prior to the 1991 Civil Rights Act, Title VII monetary damages were limited to wages and were therefore fully taxable. The Court noted its implicit recognition, however, that damages received after passage of the Civil Rights Act of 1991 would be treated differently because "the amended act signals a marked change in [Congress'] conception of the injury redressable by Title VII. ${ }^{95}$ Thus, while the Court has not yet explicitly held that Title VII cases should now be analyzed as tort cases, such a holding is implicitly compelled.

Turning from the explicit decisions of the Court, and the arguments of commentators, the analogy of Title VII to other employment torts is obvious. The central purpose of Title VII is to right the wrong created by discrimination, and to make its victims whole by permitting a civil action for damages. Although the source of this cause of action is an act of Congress, rather than the common law, ${ }^{96}$ the action is, like any other tort action, an action to redress a civil wrong, not based on contract, for which damages are sought. Examination of the theories under which Title VII actions may be brought reveals that the Court has clearly recognized Title VII as providing tort-like actions under theories of intentional

92105 Stat. at 1071 .

${ }^{93}$ See 42 U.S.C.A. \$ 1981a(b)(3) (West Supp. 1992).

94112 S. Ct. 1867 (1992).

${ }^{95} \mathrm{Id}$. at 1874 n.12. Since the plaintiffs received their damages prior to the adoption of the Civil Rights Act of 1991, this new "conception" was not "imported back ${ }^{n}$ into Title VII analysis. Accordingly, the Court held that the back pay awards were not excludable from gross income. See id.

${ }_{96}$ See, e.g., Rowland v. Christian, 443 P.2d 561, 563-64 (Cal. 1968) (holding that tort actions may arise from common law development or through legislative creation of civil wrongs). 
tort and strict liability, while implicitly recognizing a wide range of inchoate negligence theories.

\section{A. The Court's Early Analysis of Employment Discrimination \\ Cases Established Two Tort Theories of Liability- Intentional Discrimination and Strict Liability}

When Congress enacted Title VII it provided little guidance on the standard that courts should require for proof of discrimination. The Supreme Court's two earliest decisions interpreting Title VII resolved this issue ${ }^{97}$ by requiring an intent test equivalent to the standard of proof for intentional torts in one branch of cases, ${ }^{98}$ while permitting a strict liability test similar to that used in strict liability in tort in a second area. ${ }^{99}$ Generally, the Court provided that where an employee challenges policies or procedures which have a discriminatory effect, she may rely on a strict liability theory, rather than having to prove intentional discrimination. ${ }^{100}$ This doctrine is variously referred to as the "effects test," 101 the "disparate impact" theory, ${ }^{102}$ and "adverse impact analysis." 103 In contrast, where an employee challenges a specific employment decision, she must prove it was motivated by an intent to discriminate. ${ }^{104}$ This doctrine is generally described as the "intent

97 The resolution provided and described herein has been the subject of considerable recent controversy. See, e.g., Wards Cove Packing Co. v. Atonio, 490 U.S. 642, 657 (1989) (holding that the burden of proving discrimination, even in an adverse impact case, remains with the plaintiff at all times, and that the employer need only produce evidence of "legitimate business reasons" for its employment practices); Watson v. Fort Worth Bank \& Trust, 487 U.S. 977, 994, 997-98 (1988) (laying the foundation, with four Justices for the majority opinion in Wards Cove). Wards Cove was thereafter overturned by the Civil Rights Act of 1991, Pub. L. No. 102-166, 105 Stat. 1071 (1991) (amending 42 U.S.C. \$\$ 1981, 2000e). See infra text accompanying notes $155-64$.

${ }^{98}$ See McDonnell Douglas Corp. v. Green, 411 U.S. 792 (1973); infra text accompanying notes 117-23.

${ }^{99}$ See Griggs v. Duke Power Co., 401 U.S. 424 (1971); infra text accompanying notes 109-16.

${ }^{100}$ See id. at 432.

${ }^{101}$ Guardians Ass'n v. Civil Serv. Comm'n, 463 U.S. 582, 618 (1983) (Marshall, J., dissenting).

102 Dothard v. Rawlinson, 433 U.S. 321, 338 (1977); Int'l Bhd. of Teamsters v. United States, 431 U.S. 324, 335 n.15 (1977).

103 Albemarle Paper Co. v. Moody, 422 U.S. 405, 425 (1975).

${ }^{104}$ See infra text accompanying notes 117-23. 
test," 105 the "discriminatory motive test,"106 the "disparate treatment" theory, ${ }^{107}$ and "adverse treatment" analysis. ${ }^{108}$

\section{Strict Liability}

The strict liability approach is found in the Court's first Title VII case, Griggs v. Duke Power Co. ${ }^{109}$ where the Court considered what standard of proof was required to establish that an employer's job screening procedures violated the Act. Prior to the passage of Title VII, Duke Power Company had openly segregated its employees at its Draper, North Carolina power plant. Black workers were only hired into the "labor department," where even the highest wages were below the lowest wages of the other departments. On July 2, 1965, the date Title VII became effective, the company added a new requirement for employment in any department other than the labor department-achievement of passing scores on two professionally prepared "aptitude" tests. ${ }^{110}$ Transfers out of the labor department were restricted to employees who had either passed the two tests or who had completed high school.

Thirteen of the fourteen African Americans employed at the plant filed a Title VII action challenging the new requirements, which prevented them from transferring into other, higher paying, departments. The trial court concluded that the Act required proof of discriminatory intent, and that the company did not have a subjective discriminatory purpose in adopting the high ${ }_{1}$ school degree or test requirement. ${ }^{111}$ On appeal, the plaintiffs argued that even absent discriminatory intent, hiring or transfer requirements which produced discriminatory consequences were prohibited unless the requirements were job related. The Fifth Circuit rejected the argument, affirming the District Court judgment that a

105 United States v. Marengo County Comm'n, 731 F.2d 1546, 1558 n.17 (11th Cir), cert. denied, 469 U.S. 976 (1984); Nevett v. Sides, 571 F.2d 209, 237 n.8 (5th Cir. 1978) (Wisdom, J., concurring) (citing Washington v. Davis, 426 U.S. 229, 246-48 (1976)), cert. denied, 446 U.S. 951 (1980).

${ }^{106}$ Teamsters, 431 U.S. at 335 n.15.

${ }^{107}$ Id.; Geduldig v. Aiello, 417 U.S. 484, 501-02 (1974) (Brennan, J., dissenting).

108 Price Waterhouse v. Hopkins, 490 U.S. 228, 249 (1989).

109401 U.S. 424 (1971).

110 The tests were the Wonderlic Personnel Test (a "general intelligence" test) and the Bennett Mechanical Comprehension Test. See id. at 428.

${ }^{111}$ See id. at 428. 
subjective test of employer intent should govern Title VII actions. ${ }^{112}$

The Supreme Court, in a unanimous opinion by Chief Justice Burger, reversed. The Court concluded that Congress was primarily concerned with the effect of employment practices rather than with employers' intent. As Chief Justice Burger explained: "Congress directed the thrust of the Act to the consequences of employment practices, not simply the motivation. ${ }^{113}$ Without specifically using the term "strict liability," the Court adopted a strict liability test for selection devices that had a discriminatory impact. If a practice could be shown to disproportionally exclude a group protected by the Act, it was discriminatory without regard to the employer's intent. The employer was, in effect, strictly liable for its unintended but harmful conduct.

While establishing a strict liability test for discriminatory selection devices, the Court simultaneously fashioned an affirmative defense-the defense of business necessity. ${ }^{114}$ The employer could justify its selection device, despite its discriminatory impact, by showing that it was necessary to the essential operation of the business. But the burden of proving the affirmative defense of business necessity was substantial; the employer was given "the burden of showing that any given requirement [having a discriminatory impact] must have a manifest relationship to the employment in question." 115

The availability of this adverse impact/strict liability theory helped make it possible for employees to bring broad-based charges challenging systemic discrimination that could never have been proved in individual, intentional tort type cases. The potential cost to employers was substantial. ${ }^{116}$ The existence of the affirmative defense of business necessity tempered that potential cost by relieving employers of liability for their discriminatory practices when they could demonstrate that their businesses simply could not continue to operate absent their unintended discrimination.

112 See id. at 428-29.

$113 \mathrm{Id}$. at 432.

114 See id. at 431.

115 Id. at 432.

116 See, e.g., Neil C. Churchill \& John K. Shank, Affirmative Action and Guilt-Edged Goals, HARV. BUS. REV., Mar.-Apr. 1976, at 111 (describing large lawsuits and settlements). 


\section{Intentional Tort}

Because the Griggs test was concerned with a systemic type of discrimination, such as an employment selection device, it was generally invoked in class action cases on behalf of all those affected by the challenged practice. It was initially seen as having little application to cases in which an individual was challenging a particular decision depriving her of a job or an equal employment opportunity. Such individual cases were analyzed by comparing the treatment of the complaining employee with that of non-minority employees, in order to discern from the difference in treatment a wrongful motive, and were described as "disparate treatment" cases. The standard of proof in disparate treatment cases was addressed in the Supreme Court's second Title VII case, McDonnell Douglas Corp. v. Green. ${ }^{117}$

In the McDonnell Douglas case, Green, a black civil rights activist, claimed that he had been rejected by McDonnell Douglas for a job as a mechanic both because of his race and because he had been a vocal public opponent of McDonnell Douglas' past employment practices, which he alleged were racially discriminatory. ${ }^{118}$ McDonnell Douglas responded that it had rejected Green because he had engaged in illegal acts against the company. ${ }^{119}$

The Supreme Court held that in an individual discrimination case there must be proof of an intent to discriminate. The Court made it clear that the intent could be proven through circumstantial rather than direct evidence; there was no need to have the employer admit a discriminatory motive. If the plaintiff could show, for example, that she ${ }^{120}$ was qualified for an open job which remained open after her rejection, the employer must articulate a nondiscriminatory reason for its decision. ${ }^{121}$ If the employer articulated a nondiscriminatory reason, the plaintiff could establish that the

117411 U.S. 792 (1973).

118 See id. at 794. Discrimination against an applicant or employee because of her opposition to practices made unlawful by Title VII is itself a violation of the Act. See 42 U.S.C. § 2000e-3(a) (1988).

119 The acts were a "stall-in" and a "lock-in" used to disrupt the plant and dramatize the dispute over hiring and employment practices. See McDonnell Douglas, 411 U.S. at 794-96.

${ }^{120}$ Although the McDonnell Douglas decision involved race discrimination, the Court has since held that the test generally applies in any type of Title VII discriminatory treatment case. See Texas Dep't of Community Affairs v. Burdine, 450 U.S. 248, 252 (1981).

121 See McDonnell Douglas, 411 U.S. at 802. 
proffered reason was unworthy of belief, thus reviving the circumstantial evidence of discrimination as unrebutted. ${ }^{122}$ In contrast to a discriminatory impact case, in the case of an individual challenging a specific decision, a conscious intent to discriminate was the touchstone. Although the Court has made it clear that there are a wide variety of ways of establishing circumstantial proof of a discriminatory intent, it has continually reaffirmed that in the disparate treatment case, the wrong prohibited by Title VII is an intentional wrong requiring proof in some form of a conscious discriminatory motive. That wrong, at its core, is an intentional tort-an intentional wrongful interference with the rights of another person. ${ }^{123}$

To some degree, where employers have knowingly applied stereotypes $^{124}$ to assess an employee or applicant, the Court has permitted the finding of intent to rely on the use of the stereotypes, even if the intent was thus indirect. But the Court has required that the stereotypes be proved to have been "consciously" and "knowingly" applied. In Price Waterhouse v. Hopkins ${ }^{125}$ the Court held that evidence that an employer knowingly applied sexual stereotyping in a promotional decision may be used to infer an intent to discriminate. Hopkins was a senior manager for Price Waterhouse who was denied promotion to partnership. ${ }^{126}$ Her work for the firm was highly regarded, but her interpersonal relations with colleagues and staff were controversial. ${ }^{127}$ As Justice Brennan explained in the plurality opinion:

There were clear signs, though, that some of the partners reacted negatively to Hopkins' personality because she was a woman. One partner described her as "macho"; another suggested that she "overcompensated for being a woman"; a third advised

122 See id. at 804-05; see also Burdine, 450 U.S. at 256 ("'The plaintiff] must have the opportunity to demonstrate that the proffered reason was not the true reason for the employment decision.").

123 See generally W. PAGe Keeton et aL., Prosser and Keeton ON THE LAW OF TORTS $\$ 8$, at 36 (5th ed. 1984) (noting that the concern of intentional tort is intent to act in a manner which invades the interest of another in a way that the law forbids).

124 On the application of stereotypes as a form of sex discrimination in employment, see generally Taub, supra note 17.

125490 U.S. 228 (1989).

126 Technically, under Price Waterhouse's procedures she was initially proposed for partnership, with the decision deferred, and then not reproposed. See id. at 23132.

127 See id. at 233-35. 
her to take "a course at charm school" .... But it was the man who, as Judge Gesell found, bore responsibility for explaining to Hopkins the reasons for the Policy Board's decision to place her candidacy on hold who delivered the coup de grace: in order to improve her chances for partnership, [he] advised, Hopkins should "walk more femininely, talk more femininely, dress more femininely, wear make-up, have her hair styled, and wear jewelry." ${ }^{128}$

The district court determined that although there were legitimate complaints about Hopkins' interpersonal skills, and that these were not utilized as a pretext for discrimination, that some of the partners participating in the partnership vote had been influenced by sex-stereotyping, or gender-biased views of appropriate workplace demeanor, ${ }^{129}$ and that the firm had discriminated against Hopkins "by consciously giving credence and effect to partners' comments that resulted from sex stereotyping." ${ }^{\text {130 }}$ As to this portion of the district court decision, the court of appeals ${ }^{131}$ and Supreme Court affirmed. ${ }^{132}$

In Justice Brennan's plurality opinion, the Court held that the evidence that the employer knowingly considered evaluations motivated by stereotypical notions about women was sufficient to support the finding that sex discrimination improperly played a role in the employment decision. ${ }^{138}$ This is a step removed from a direct discriminatory motive, but it nonetheless depends on a form of constructive intent, or inferred intent. ${ }^{134}$ Although the Court could have reached the conclusion that the employer's gender stereotyping was a violation of the employee's right to an individualized nondiscriminatory determination, and thus, in essence a form

128 Id. at 235 (citations omitted).

129 See id. at 236.

${ }^{130} \mathrm{Id}$. at 237.

${ }^{131}$ See Hopkins v. Price Waterhouse, 825 F.2d 458, 468 (D.C. Cir. 1987).

132 See Price Waterhouse, 490 U.S. at 255-58. Another portion of Hopkins, concerning the question of whether an employer could escape liability if it had mixed motives for its decision, was overturned by the 1991 Civil Rights Act. See 42 U.S.C.A $\S 2000 \mathrm{e}-2(\mathrm{~m})$ (West Supp. 1992).

138 See Price Waterhouse, 490 U.S. at 250-52. Justice Brennan pointed out that it does not "require expertise in psychology to know that, if an employee's flawed 'interpersonal skills' can be corrected by a soft-hued suit or a new shade of lipstick, perhaps it is the employee's sex and not her interpersonal skills that has drawn the criticism." Id. at 256.

${ }^{134}$ For other cases in which intent was inferred from conduct, see Barbano v. Madison County, 922 F.2d 139, 142 (2d Cir. 1990); Blake v. J.C. Penney Co., 894 F.2d 274, 278 (8th Cir. 1990); Perry v. Kunz, 878 F.2d 1056, 1059 (8th Cir. 1989); Brooks v. Woodline Motor Freight, Inc., 852 F.2d 1061, 1063 (8th Cir. 1988). 
of negligence, it chose instead to reaffirm the importance of discriminatory motive as the touchstone of intentional discrimination.

Without explicitly using tort language, the Court explained the intentional tort/strict liability distinction in International Brotherhood of Teamsters $v$. United States: ${ }^{135}$

"Disparate treatment" such as alleged in the present case is the most easily understood type of discrimination. The employer simply treats some people less favorably than others because of their race, color, religion, sex, or national origin. Proof of discriminatory motive is critical, although it can in some situations be inferred from the mere fact of differences in treatment. ...

Claims of disparate treatment may be distinguished from claims that stress "disparate impact." The latter involve employment practices that are facially neutral in their treatment of different groups but that in fact fall more harshly on one group than another and cannot be justified by business necessity. Proof of discriminatory motive, we have held, is not required under a disparate-impact theory. ${ }^{136}$

3. Watson, Wards Cove, and the 1991 Civil Rights Actthe Abandonment and Rebirth of Strict Liability

At the very heart of the Griggs strict liability doctrine was the absence of malice; liability did not carry with it any conclusion about fault, or wrongdoing. But beginning in 1977 the Court attempted to move its adverse impact analysis away from strict liability. At the core of the Rehnquist Court's view of adverse impact discrimination was proof of fault; in the process, formerly strict liability cases were subjected to an intentional discrimination test. The response was the congressional passage of the 1991 Civil Rights Act. That Act revived strict liability analysis, and, as will be discussed in Part II.B.3, gave new life to negligence analysis as well.

The attempt to abandon strict liability began with the decision in Watson v. Fort Worth Bank $\mathcal{E}$ Trust, ${ }^{137}$ where the Court considered the question of whether adverse impact analysis could be properly applied to the use of subjective evaluations in promotion decisions. Watson, a black woman, had applied on four occasions

\footnotetext{
135431 U.S. 324 (1977).

136 Id. at 335 n.15 (citations omitted).

137487 U.S. 977 (1988).
} 
for promotions from her job as a bank teller. In each case she was rejected in favor of a white candidate. The bank had no formal criteria for evaluating candidates for the positions she sought, instead relying on the subjective evaluations of the supervisors who knew the candidates. All of the supervisors evaluating Watson were white. ${ }^{138}$ At least one of those supervisors commented that the "position was a big responsibility with 'a lot of money . . . for blacks to have to count." 139 In the district court, Watson attempted to use both intentional discrimination and adverse impact theories of liability, but the district court concluded that in an individual case focusing on specific decisions only the McDonnell Douglas intentional discrimination analysis could be applied, and that Watson had failed to prove an intent to discriminate. ${ }^{140}$ The Fifth Circuit affirmed. ${ }^{141}$

Justice O'Connor authored an opinion which was in part a majority opinion and in part a lead opinion by an evenly split Court, explaining for four of the eight participating justices how the decision should be applied. ${ }^{142}$ All eight participating members agreed that subjective hiring or promotion criteria could be properly subjected to adverse impact analysis. ${ }^{143}$ But in so doing, four members ${ }^{144}$ attempted to redefine the underlying premise of adverse impact cases.

Justice O'Connor's opinion began by discussing the theoretical underpinnings of adverse impact analysis. Moving away from the clear line drawn in Teamsters between adverse treatment and adverse impact cases, ${ }^{145}$ the opinion stated:

The distinguishing features of the factual issues that typically dominate in disparate impact cases do not imply that the ultimate

138 See id. at 982.

139 Id. at 990.

140 See id. at 983-84.

141 See id. at 984 (affirming the district court holding that plaintiff had failed to prove her claim, but vacating the portions of the judgment affecting other members of the black job applicant class so as to avoid inequitable preclusion).

112 Parts I, II-A, II-B, and III were joined by all members of the Court except Justice Kennedy, who took no part in the decision, and Justice Stevens, who wrote separately, concurring only in the judgment. See id. at 982, 1000, 1011. Parts II.C and II.D were joined by Chief Justice Rehnquist and Justices White and Scalia; on those parts Justice Blackmun authored a separate opinion joined by Justices Brennan and Marshall. See id. at 982, 1000.

${ }^{143}$ See id. at 989-91, 1011.

${ }^{144}$ Chief Justice Rehnquist and Justices O'Connor, White and Scalia.

${ }^{145}$ See supra note 136 and accompanying text. 
legal issue is different than in cases where disparate treatment analysis is used. Nor do we think it is appropriate to hold a defendant liable for unintentional discrimination on the basis of less evidence than is required to prove intentional discrimination. Rather, the necessary premise of the disparate impact approach is that some employment practices, adopted without a deliberately discriminatory motive, may in operation be functionally equivalent to intentional discrimination. ${ }^{146}$

This analysis of unintended adverse impact discrimination as "functionally equivalent" to intentional discrimination appeared to mark a dramatic deviation from Teamsters. The decision appears to suggest that all discrimination must be intentional to be wrongful, and that the adverse impact test is simply an alternative means of finding discriminatory intent.

This reading becomes critical in considering the portion of the opinion which did not command a majority. There, Justice O'Connor went on to discuss the need for new evidentiary standards to be applied in adverse impact cases. ${ }^{147}$ She explained that permitting adverse impact challenges to subjective selection practices created a substantial risk that many employers would be subjected to liability merely because their workforce failed to precisely mirror the available labor pool. If such a statistical showing required an employer to prove a manifest relationship between the subjective selection process and the employment in question, many employers would face the risk of enormous liability. Faced with such liability, Justice O'Connor feared that employers would instead utilize illegal hiring quotas designed to avoid any appearance of discrimination:

If quotas and preferential treatment become the only cost-effective means of avoiding expensive litigation and potentially catastrophic liability, such measures will be widely adopted. The prudent employer will be careful to ensure that its programs are discussed in euphemistic terms, but will be equally careful to ensure that the quotas are met. ${ }^{148}$

In order to avoid this risk that easy proof of discrimination would lead to the use of improper quotas, Justice O'Connor called for two "constraints that operate to keep that [adverse impact]

146 Watson, 487 U.S. at 987 (citation omitted).

147 See id. at 991.

148 Id. at 993. 
analysis within its proper bounds. ${ }^{149}$ The first was a requirement that the plaintiff identify the specific practice causing the discriminatory impact, rather than generally challenge the bottom line results of the employer's screening. "[T]he plaintiff is in our view responsible for isolating and identifying the specific employment practices that are allegedly responsible for any observed statistical disparities. Cf. Connecticut $v$. Teal. 150 Thus, if an employer used a series of screening devices to choose employees, and the end result was the elimination of women or minorities from the candidates chosen, the plaintiff challenging the selection process would bear the burden of proving which of the screening devices used was discriminatory.

As a second constraint, Justice O'Connor recommended revising the business necessity defense by shifting the burden of proof from the defendant to the plaintiff. ${ }^{151}$ She did so by again blurring the line between the Griggs and McDonnell Douglas lines of cases. ${ }^{152}$

Under the Griggs formulation, business necessity operated as an affirmative defense; the burden of persuasion was placed squarely on the defendant. Once the plaintiff had established that the selection device had a discriminatory impact, the employer was required to "prove"153 business necessity. By contrast, in the McDonnell Douglas intentional discrimination cases, once the plaintiff established a prima facie case the burden of production shifted to the defendant, but the burden of persuasion remained with the plaintiff. ${ }^{154}$ The articulation of a nondiscriminatory

149 Id. at 994 .

${ }^{150} I d$. (citation omitted). The citation to Connecticut v. Teal, 457 U.S. 440 (1982), borders on irony. In Teal, the Court held that an employer must use the business necessity defense to justify each discriminatory step in a selection process, rather than rely on having achieved a nondiscriminatory ultimate result. See id., 457 U.S. at 44345. Requiring the plaintiff to identify the point in the selection process where the employer's conduct produced the discriminatory result turns Teal on its head.

${ }^{151}$ See Watson, 487 U.S. at 994.

152 See Watson, 487 U.S. at 1001-02 \& n.3 (Blackmun, J., concurring).

153 Dothard v. Rawlingson, 433 U.S. 321,329 (1977) (" $[$ T] he employer must meet 'the burden of showing that any given requirement [has] . . . a manifest relationship to the employment in question." (quoting Griggs v. Duke Power Co., 401 U.S. 424, 432 (1971))); Albemarle v. Paper Co., 422 U.S. 405, 425 (1975) (stating that under Griggs, an employer can rebut the plaintiff's showing by proving its employment criteria to be job related); see also Wards Cove Packing Co. v. Atonio, 490 U.S. 642, 670 (1989) (Stevens, J., dissenting) (" $[\mathrm{W}]$ hen an employer is faced with sufficient proof of disparate impact, its only recourse is to justify the practice by explaining why it is necessary to the operation of business."); Watson, 487 U.S. at 1001 (Blackmun, J., concurring).

${ }^{154}$ See Texas Dep't of Community Affairs v. Burdine, 450 U.S. 248, 254-56 (1981); 
reason was merely a method of dispelling the plaintiff's prima facie showing, not an affirmative defense. Thus, the articulation of a nondiscriminatory reason in an intentional discrimination case was relatively easy, while the proof of business necessity in a strict liability/adverse impact case was quite difficult. Using the McDonnell Douglas formulation to justify shifting the plaintiff's burden under a Griggs analysis substantially undermined the analytical differences between the two lines of cases. It was a precursor of the major development of the following term.

The Watson Court's blurring of intentional and strict liability discrimination only commanded four votes in 1988. In 1989, it gained a decisive fifth vote in Wards Cove Packing Co. v. Atonio. ${ }^{155}$ Wards Cove and a second company operated salmon canneries in Alaska. Each employed two classes of workers: "cannery workers," who held unskilled fish packing positions, and "noncannery workers," who held mostly skilled and semi-skilled positions. Cannery workers were hired through a predominantly Filipino union local in Seattle and through recruitment in Alaskan Indian villages; most were non-white. Noncannery workers were hired through other offices in Oregon and Washington; most were white. Hiring preferences were accorded to former employees and their family members. The workers' accommodations were segregated by job category. Noncannery workers had separate and apparently superior dorms and dining halls, and were virtually all paid more than cannery workers. The companies did not permit cannery workers to apply for promotion into noncannery jobs. A group of non-white cannery workers brought an action challenging, in part, the separate hiring channels, the nepotism, and the practice of not promoting from within. ${ }^{156}$

When the case reached the Supreme Court, ${ }^{157}$ a new five member majority led by Justice White adopted the O'Connor positions from Watson that the plaintiff must prove which specific practice caused the discriminatory effect, ${ }^{158}$ and that the business

see also Watson, 487 U.S. at 1001-02 (Blackmun, J., concurring).

155490 U.S. at 644 . Justice White wrote for a five member majority; he was joined

by Chief Justice Rehnquist and Justices O'Connor, Scalia, and Kennedy. See id.

${ }^{156}$ See id. at $647-48$.

157 The district court ruled in favor of the companies. See id. at 648 . The Ninth Circuit affirmed, but then reversed following an en banc hearing. See id. The Supreme Court reversed the circuit court. See id. at 661 .

${ }^{158}$ See $i d$. at 656 (holding that the plaintiff must identify which particular practice is discriminatory). 
necessity defense is not a burden of proof-shifting affirmative defense. ${ }^{159}$ The Wards Cove majority dropped the Court's prior description of business necessity and instituted a new test. Instead of requiring the employer to prove a "manifest relationship to the employment in question, ${ }^{n 160}$ the Court required only that the employer produce evidence (but not prove) that the "challenged practice serves, in a significant way, the legitimate employment goals of the employer."161 Abandoning the language of necessity, the Court held that the employer need only articulate how the practice serves its goals; "there is no requirement that the challenged practice be 'essential' or 'indispensable' to the employer's business for it to pass muster." 162 Relying on Watson, and its blurring of the distinction between the proof of intentional discrimination and adverse impact/strict liability cases, the Court pointed to the McDonnell Douglas line of cases to assert that in all discrimination cases the burden of persuasion remains with the plaintiff at all times. "[T] he employer carries the burden of producing evidence of a business justification for his employment practice. The burden of persuasion, however, remains with the disparate-impact plaintiff." 163

By placing the burden of proof on the plaintiff throughout the adverse impact case, by changing the business necessity defense to a legitimate business goals defense, and by blurring the distinction between adverse impact and intentional discrimination, the Court effectively attempted to retreat from a strict liability standard to a fault standard. Its retreat failed only through legislative intervention in the form of the Civil Rights Act of 1991. That Act restored the law to its pre-Wards Cove form:

An unlawful employment practice based on disparate impact is established under this subchapter only if ... a complaining party demonstrates that a respondent uses a particular employment practice that causes a disparate impact on the basis of race, color, religion, sex, or national origin and the respondent fails to demonstrate that the challenged practice is job related for the position in question and consistent with business necessity ....164

159 See id. at 659 (holding that the burden of proof remains with the plaintiff).

160 Griggs v. Duke Power Co., 401 U.S. 424, 432 (1971).

161 Wards Cove, 490 U.S. at 659 (citations omitted).

162 Id.

163 Id.

${ }^{164} 42$ U.S.C.A. $\S 2000 \mathrm{e}-2(k)(1)(A)$ (West Supp. 1992). 
B. The Origins of Negligent Employment Discrimination: The Less

Discriminatory Alternative as a Negligence Alternate Within the Doctrine of Strict Liability Discrimination

1. The Development Of The Less Discriminatory Alternative Test

Despite the clear dichotomy suggested by Teamsters in footnote fifteen, ${ }^{165}$ the Court had by then already begun to articulate a third approach to discrimination within the adverse impact/strict liability doctrine-the less discriminatory alternative doctrine. This doctrine was first articulated in Albemarle Paper Co. v. Moody. ${ }^{166}$ In Albemarle, a class of black employees sued their employer, a paper mill. Like the Duke Power Company, the Albemarle Paper Company strictly segregated its workers prior to the passage of Title VII, with black employees restricted to the lowest paying positions. When Title VII became effective, the company instituted a seniority system that prevented employees who were transferring to new jobs from taking their seniority with them, and required transferring employees to hold a high school degree and take two "aptitude" tests. ${ }^{167}$ The Supreme Court affirmed a holding that the seniority system was discriminatory and reversed a decision that the aptitude tests were job related. ${ }^{168}$ The Court reasoned, in dicta, that if the employee proved that the employer's selection device had a discriminatory impact, and the employer then met its burden by validating its procedures under the business necessity test, the employee could nonetheless prevail if she could "show that other tests or selection devices, without a similarly undesirable racial effect, would also serve the employer's legitimate interest." ${ }^{169}$ The employer's failure to use the less discriminatory selection device was itself a violation of Title VII. ${ }^{170}$ This test came to be

165 See International Bhd. of Teamsters v. United States, 431 U.S. 324, 335 n.15 (1977); supra note 136 and accompanying text.

166422 U.S. 405,425 (1975).

167 See id. at $409-11$.

168 See id. at $435-36$.

169 Id. at 425 .

170 Many of the circuit courts applied the Albemarle dicta. See Mozee v. American Commercial Marine Serv. Co., 940 F.2d 1036, 1050 (7th Cir. 1991); Nash v. Consol. Jacksonville, 837 F.2d 1534, 1536 (11th Cir. 1988), vacated, 490 U.S. 1103 (1989), reinstated, 905 F.2d 355 (11th Cir. 1990), cert. denied, 111 S. Ct. 967 (1991); Clady v. County of L.A., 770 F.2d 1421, 1428 (9th Cir. 1985), cert. denied, 475 U.S. 1109 (1986); EEOC v. St. Louis-S.F. Ry., 743 F.2d 739, 742 (10th Cir. 1984); Walker v. Jefferson County Home, 726 F.2d 1554, 1559 (11th Cir. 1984); Zuniga v. Kleberg County Hosp., 692 F.2d 986, 989 (5th Cir. 1982); Clanton v. Orleans Parish Sch. Bd., 
known as the "alternative selection"171 test or "less discriminatory alternative ${ }^{\text {"172 }}$ test.

\section{The Relationship of the Less Discriminatory Alternative Test to the Doctrine of Negligence}

The formulation of a less discriminatory alternative test encourages the consideration of a negligence theory of employment discrimination. Negligence, at its core, is the breach of a duty recognized by law for the protection of others. ${ }^{173}$ Such a duty, or obligation to conform to a minimum standard of conduct, may be determined through the development of the common law, or by legislative action, or administrative regulation. ${ }^{174}$ In the employment context, such duties and obligations include providing a physically safe workplace, ${ }^{175}$ protecting employees from unfit coemployees and supervisors, ${ }^{176}$ and refraining from terminations which violate public policy. ${ }^{177}$ The relationship between the employee and employer may be described as a "special relationship," requiring a greater responsibility from the employer, vis-a-vis

649 F.2d 1084, 1098 (5th Cir. 1981); Chrisner v. Complete Auto Transit, 645 F.2d 1251, 1263 (6th Cir. 1981); Grant v. Bethlehem Steel Corp., 635 F.2d 1007, 1015 (2d Cir. 1980), cert. denied, 452 U.S. 940 (1981); Solo Cup Co. v. Federal Ins. Co., 619 F.2d 1178, 1186-87 (7th Cir.), cert. denied, 449 U.S. 1033 (1980); see also Easley v. Anheuser-Busch Inc., 572 F. Supp. 402, 410 (E.D. Mo. 1983) (finding that an alternative selection procedure was available), modified, $758 \mathrm{~F} .2 \mathrm{~d} 251$ (8th Cir. 1985).

171 See, e.g., Clady, 770 F.2d at 1428 ("The plaintiff then may attempt to rebut the defendant's evidence by showing that although job-related, the test does not constitute a business necessity because an alternative selection device exists which would have comparable business utility and less adverse impact." (citation omitted)).

172 See Mozee, 940 F.2d at 1050; Zuniga, 692 F.2d at 992; Clanton, 649 F.2d at 1098.

173 See, e.g., RESTATEMENT (SECOND) OF TORTS § 282 (1965); KEETON ET AL., supra note $123, \S 30$.

174 See RESTATEMENT (SECOND) OF TORTS § 285 (1965).

175 See, e.g., Hentzel v. Singer Co., 188 Cal. Rptr. 159, 164 (Ct. App. 1982) (holding that an employer has an obligation to provide a safe workplace, and that terminating an employee for complaints about workplace safety is tortious).

${ }^{176}$ See, e.g., Najera v. Southern Pac. Co., 13 Cal. Rptr. 146, 148 (Ct. App. 1961) (permitting tort action by employee against employer for "negligent retention" of a dangerous co-employee).

177 See, e.g., Foley v. Interactive Data Corp., 765 P.2d 373, 376-80 (Cal. 1988) (holding that termination in violation of public policy is tortious); Tameny v. Atlantic Richfield Co., 610 P.2d 1330, 1336-37 (Cal. 1980) (holding that discharge of employee for refusing to participate in illegal price-fixing scheme is tortious). 
the employee, than the general duties persons have toward others. ${ }^{178}$

Tort actions arising from this special relationship are often premised on the employer's knowledge of a risk of harm, or of a less potentially harmful way to accomplish some task. ${ }^{179}$ The law of negligence requires persons who choose to become employers to enter into the employment relationship with care, in order to protect those persons seeking employment, those who become employed, and the general public. When a failure to exercise due care in the manner of choosing employees, or maintaining or terminating their employment, causes harm, the employer is responsible for the costs of that harm.

The Albemarle test can be best understood when it is examined in light of the duties of one in a special relationship. To put Griggs and Albemarle in the more common tort usage, Title VII establishes a duty on the part of employers not to discriminate. ${ }^{180}$ Under the Griggs line of authority, that duty includes a duty not to adopt or use selection devices that have a discriminatory impact, unless manifestly necessary to the operations of the business. Under Albemarle, where the selection device's discriminatory impact is conditionally privileged under the business necessity defense, the employer nonetheless has a further duty to determine whether a less discriminatory alternative that meets its legitimate needs exists. Where there is a less discriminatory alternative, the failure to adopt the less discriminatory device renders the employer liable to those harmed by the use of the more discriminatory device. Liability is established because the employer could have provided greater protection against discrimination without sacrificing its legitimate and necessary business interests. If a less discriminatory alternative exists, the employer has failed to act reasonably-it has breached its duty of care-by engaging in avoidable discrimination.

Like all tests of reasonableness, a balance lies at the heart of the standard. On one side lies that which the employer knew or should have known about the relative risks of harm in the various available selection devices. On the other side lies the employer's necessary business practices. Where the plaintiff proves that the employer's selection of the more discriminatory device cannot be justified by reference to the employer's necessary and legitimate interests, the employer has been shown to have breached its duty not to discrimi-

178 See RESTATEMENT (SECOND) OF TORTS § 314B (1965).

179 See KEETON ET AL., supra note 123, \$ 33, at 201-02.

180 See RESTATEMENT (SECOND) OF TORTS §§ 285(b), 286 (1965). 
nate. The employer's liability is not the result of an intent to discriminate, nor is the employer strictly liable. Rather, the employer is liable because it breached a duty to avoid discriminatory consequences by failing to adopt a less discriminatory alternative where such an alternative was available. The employer's actions are negligent, and it is thus liable under Title VII.

\section{The Death and Re-birth of the Less Discriminatory}

Alternative Test: Wards Cove and The 1991 Civil Rights Act

The Court in Wards Cove, having laid waste to the Griggs doctrine of strict liability, also went on to eviscerate the Albemarle less discriminatory alternative theory. The Court noted with approval the long-standing Albemarle principle that if a selection device meets the business necessity test, the plaintiff may still prevail by showing that a less discriminatory selection device would also serve the employer's legitimate interests. But the Court dramatically altered the effect of a finding that an employer had failed to adopt a less discriminatory alternative. Under Albemarle and its progeny, the employer's failure to adopt the less discriminatory alternative was sufficient to prove a violation of the Act. In Wards Cove, the Court held that if the plaintiff proved that the employer had failed to adopt a less discriminatory alternative, the employer could escape all liability merely by agreeing, at that time, to adopt the less discriminatory procedure. In essence, the employer was free to ignore a less discriminatory selection device until the plaintiff's case was proven at trial. Only then did the employer face the choice of changing its discriminatory policy or incurring liability. The Court reasoned that in the face of proof at trial of both a discriminatory impact and a less discriminatory alternative, an employer's failure to adopt such less discriminatory alternatives would constitute evidence of pretext, belying the claim that the discriminatory selection device was being employed for nondiscriminatory reasons. ${ }^{181}$ The Court either failed to consider, or was unswayed by the problem, that if there was no cost in choosing the more discriminatory alternative, there would be no incentive to choose the less discriminatory alternative. Under the Wards Cove rule, an employer had no reason to choose a less discriminatory selection device over a more discriminatory device until a law suit had proceeded all the way to trial, at which point all

${ }^{181}$ See Wards Cove Packing Co. v. Atonio, 490 U.S. 642, 660-61 (1989). 
liability could then be avoided by the simple expedient of changing policies.

This effective abandonment of the less discriminatory alternative test, however, met the same fate as the Court's attempt to abandon the Griggs test. The 1991 Civil Rights Act has restored the doctrine, providing that an unlawful employment practice based on disparate impact is established under Title VII if the complaining party demonstrates the existence of a less discriminatory alternative employment practice, in accordance with the law as it existed on June 4, 1989, the day before ${ }^{182}$ Wards Cove was decided on June 5, 1989.183 Thus, the existence of a negligence-like approach, within the general theory of the adverse impact theory of discrimination, has been approved by the Congress, and is explicitly a part of Title VII. This Congressional ratification demonstrates that, if discriminatory alternatives are available, employers are liable under Title VII for adopting discriminatory tests, even if the tests serve legitimate business interests. Wholly aside from the Griggs strict liability approach, employers are also liable for the harm caused to women or minority applicants if they adopt a selection device which is discriminatory in its effects when the risk of such a discriminatory result could have been avoided by using a less harmful selection device. Following the passage of the new Act and the reinstitution of the Griggs test, the employer must establish both business necessity and the absence of a less discriminatory alternative. Even if the selection device meets the business necessity test, if the employer knew or should have known of a less discriminatory device that met its legitimate needs, it should have avoided the harm caused to women and minorities by using the less discriminatory device. By acting carelessly or unreasonably in choosing the less discriminatory device, the employer has harmed the women and minority applicants, as well as the society as a whole. An intent to cause the harm may not have been present, but in passing Title VII the Congress was concerned with the consequences of discrimination, not simply the motivation.

Underlying the Congressional focus on the consequences of discrimination, as opposed to discriminatory intent, may be an implicit recognition of the existence of unconscious discrimination, and its importance in the analysis of Title VII cases. If Congress, in

182 See 42 U.S.C.A. \$ 2000e-2(k)(1)(A)(ii)-2(k)(1)(C) (West Supp. 1992).

183 See Wards Cove, 490 U.S. at 642. 
1964 and again in 1991, were merely concerned with the intentional tort model of employment discrimination, it would have either disavowed Griggs or failed to pass the 1991 Act. But Congress clearly concluded that intentional discrimination was only part of the problem. In approving the Griggs and Albemarle tests, the 1991 Act recognizes that the problem of employment discrimination is far broader than the problem of intentional wrongdoing; it extends to the negligent adoption of a selection device which has a discriminatory impact not required by business necessity, and the negligent adoption of a discriminatory device which may be justified by business necessity but is not the least discriminatory alternative. If motive were the touchstone of all discrimination, the Court's disavowal of the unintentional discrimination tests would have been sustained by Congress. Underlying these tests is the recognition that employers may act out of motives that are not consciously discriminatory, but are either unconscious of discrimination, or are unconsciously discriminatory.

\section{The Duty to Accommodate Differences: The Origins of Liability for Failing to Act}

In Teamsters, the Court's attempt to describe all employment discrimination as coming within the Griggs or McDonnell Douglas approaches to discrimination failed to consider a third branch of discrimination analysis-liability for the failure to prevent discrimination from occurring. This basis of liability has its roots in those cases in which an employer was charged with failing to accommodate an employee's protected status, such as her religion, pregnancy, or disability. At its heart, this theory too is essentially based on negligence; the employer is liable not because of a discriminatory act, but because of its failure to comply with a duty to take certain actions to reasonably protect its employees and applicants. The recognition of a duty to accommodate certain differences further demonstrates that a theory of negligent discrimination is already firmly rooted in Title VII.

\section{Accommodation of Religious Practices}

Title VII, as originally enacted, was silent regarding the nature of the duty not to discriminate based on religion. It simply provided that employers could not "fail or refuse to hire or to discharge any individual, or otherwise discriminate against any individual with respect to his compensation, terms, conditions, or 
privileges of employment, because of such individual's ... religion." 184

In 1966, the EEOG adopted guidelines which interpreted the Act to require an intent to discriminate, but simultaneously provided that employers be required to accommodate the religious beliefs and practices of their employees. Regarding intent, the guidelines provided that an employer:

may prescribe the normal work week and foreseeable overtime requirements, and, absent an intent on the part of the employer to discriminate on religious grounds, a job applicant or employee who accepted the job knowing or having reason to believe that such requirements would conflict with his religious obligations is not entitled to demand any alteration in such requirements to accommodate his religious needs. ${ }^{185}$

Alongside this requirement that a complaining employee prove an intent to discriminate, the guidelines further provided that "the duty not to discriminate on religious grounds includes an obligation on the part of the employer to accommodate the reasonable religious needs of employees . . . where such accommodation can be made without serious inconvenience to the conduct of the business." 186

Just one year later, in 1967, the EEOC modified its guidelines to provide that "the duty not to discriminate on religious grounds ... includes an obligation on the part of the employer to make reasonable accommodations to the religious needs of employees and prospective employees where such accommodations can be made without undue hardship on the conduct of the employer's business." 187 The 1967 guideline contained two significant amendments to the 1966 version. First, employers were no longer required to accommodate the "reasonable religious needs of employees," 188 but to make "reasonable accommodations to the religious needs of employees. ${ }^{n 189}$ Second, the language premising

18442 U.S.C. $\$ 2000 \mathrm{e}-2$ (a)(1) (West 1988).

18529 C.F.R. \& 1605.1(b)(3) (1967).

${ }^{186} I d . \S 1605.1(\mathrm{a})(2)(1967)$.

18729 C.F.R. § 1605.1(b) (1968).

18829 C.F.R. § 1605.1(a)(2) (1967).

18929 C.F.R. $\$ 1605.1$ (b) (1968). This corrective amendment avoided what would otherwise have been a serious First Amendment entanglement problem, in which courts would be required to determine not the reasonableness of a requested accommodation, but instead the reasonableness of a religious practice. Under such a standard, for example, a court might be required to determine whether it was reasonable for Moslems and Jews to refrain from eating pork, or for Jews and Seventh 
liability on an intent to discriminate was completely removed from the guideline; the duty of reasonable accommodation applied to all employment decisions having an impact on an employees' religious practices. Thus, under the 1967 guidelines, the EEOC recognized that discrimination had a broader meaning than traditional adverse treatment; treating people the same when their religious practices required them to be treated differently constituted unlawful discrimination.

The nature of the duty to accommodate was first tested in Dewey v. Reynolds Metals Co. ${ }^{190}$ Dewey, a member of the Faith Reformed Church, was discharged when he refused to work overtime on Sunday because it interfered with his religious beliefs. The district court adopted the EEOG guidelines as a proper interpretation of the statutory ban on religious discrimination and found that because Reynolds failed to either reasonably accommodate Dewey's religious beliefs or demonstrate undue hardship, Reynolds had discriminated against Dewey on the basis of religion. The Sixth Circuit reversed and found that the district court had improperly applied the 1967 version of EEOC guideline section 1605.1 retroactively. The court stated that the 1966 guideline should have been applied. Moreover, the Sixth Circuit held that Reynolds could also avoid liability under the 1967 guideline because it reasonably accommodated Dewey's religious practices by permitting him to find replacements for his Sunday shifts. ${ }^{191}$

The Supreme Court granted certiorari and held oral argument. In a per curiam opinion, an equally divided Court affirmed the Sixth Circuit's determination. ${ }^{192}$ As argued by the parties and amici curiae, ${ }^{193}$ the critical issue was whether Title VII could properly be interpreted to require any duty of accommodation, and, if so, the extent of that duty.

In response to Dewey, Congress amended Title VII in 1972 to explicitly require reasonable accommodation: “[ $t]$ he term 'religion' includes all aspects of religious observance and practice, as well as belief, unless an employer demonstrates that he is unable to

Day Adventists to celebrate the Sabbath from Friday to Saturday.

190300 F. Supp. 709 (W.D. Mich. 1969), rev'd, 429 F.2d 324 (6th Cir. 1970), affd, 402 U.S. 689 (1971) (per curiam).

${ }^{191}$ See Dewey, 429 F.2d at 331.

192 See Dewey, 402 U.S. at 689.

${ }^{193}$ Appearing in support of affirmance was the United States Chamber of Commerce. Appearing to urge reversal were the United States, the National Jewish Commission on Law and Public Affairs, and the American Jewish Congress. See id. 
reasonably accommodate to an employee's or prospective employee's religious observance or practice without undue hardship on the conduct of the employer's business. ${ }^{194}$ The statutory duty to reasonably accommodate an employee's religious practices was subsequently upheld by the Court in Trans World Airlines, Inc. $v$. Hardison ${ }^{195}$ and Ansonia Board of Education v. Philbrook. ${ }^{196}$

Although the Court has not used the language of negligence in upholding the statutory duty to accommodate, the core concept is nonetheless present. In requiring employers to reasonably accommodate employee's religious practices, employers are held to a duty of reasonable care. It is not enough that they treat all persons equally to avoid liability for discrimination, they must take affirmative protective steps to treat certain employees differently and better. An employer's benign neglect in the face of a proper request for accommodation results in liability, not because the employer has engaged in an intentional wrong, but because it has failed to conform its conduct with that which is statutorily determined to be the behavior of a reasonable employer.

\section{Accommodation of Pregnancy}

A second area in which the duty to accommodate has become an important aspect of Title VII analysis is that of pregnancy discrimination. The Supreme Court first addressed such discrimination under Title VII ${ }^{197}$ in 1976 in Gilbert v. General Electric Co. ${ }^{198}$ Gilbert, a General Electric employee, became pregnant and sought a paid disability leave under the company's disability plan. Her claim was denied because the plan covered all nonoccupational sicknesses and accidents except for disabilities arising from pregnancy, miscarriage, or childbirth.

Gilbert filed a Title VII action asserting that the exclusion of pregnancy benefits constituted sex discrimination. The district court ruled in her favor, holding that the exclusion was prohibited sex discrimination. ${ }^{199}$ The Fourth Circuit affirmed. ${ }^{200}$ The Su-

19442 U.S.C. $\$ 2000 \mathrm{e}(\mathrm{j})(1988)$.

195432 U.S. 63, 74 (1977).

196479 U.S. 60,63 \& n.1 (1986).

197 The Court had addressed the issue under the Constitution in Geduldig v. Aiello, 417 U.S. 484 (1974), a case in which the Court held that a state unemployment disability program that excludes coverage for disability resulting from pregnancy does not violate the Fourteenth Amendment.

198429 U.S. 125 (1976).

${ }^{199}$ See Gilbert v. General Elec. Co., 375 F. Supp. 367, 386 (E.D. Va. 1974), affd, 
preme Court, in a 5-4 decision authored by Justice Rehnquist, held that General Electric's benefits plan did not violate Title VII. ${ }^{201}$ The Court reasoned that General Electric's plan was nondiscriminatory because "there is no risk from which men are protected and women are not ... [and] no risk from which women are protected and men are not. ${ }^{202}$ In other words, the plan excluded pregnant men, as well as pregnant women, without regard for their gender! The Court further held that the exclusion of pregnancy from the benefits plan could not be judged a pretext for intentional discrimination against women because, although confined to women, pregnancy is significantly different from the other covered disabilities. ${ }^{203}$

In response to Gilbert, Congress amended Title VII to prohibit discrimination on the basis of pregnancy in the Pregnancy Discrimination Act of 1978 (PDA). ${ }^{204}$ The PDA added the following subsection to Title VII:

The terms "because of sex" or "on the basis of sex" include... because of or on the basis of pregnancy, childbirth, or related medical conditions; and women affected by pregnancy, ... shall be treated the same for all employment-related purposes, including receipt of benefits under fringe benefit programs, as other persons not so affected but similar in their ability or inability to work $\ldots . .205$

The Congressional purpose of the PDA was to restore the interpretation of Title VII to protect all persons from sex discrimination, including pregnant women, as it stood before Gilbert. ${ }^{206}$

In the aftermath of Gilbert and the PDA, debate arose concerning whether pregnant women should be given "equal treatment" or "special accommodations" in the workplace. To the extent that it defines discrimination, the PDA appears to set forth an equal treatment approach; pregnant women were to be treated the same as nonpregnant people with similar working abilities. Some argued

519 F.2d 661 (4th Cir. 1975), rev'd, 429 U.S. 125 (1976).

200 See Gilbert v. General Elec. Co., 519 F.2d 661 (4th Cir. 1975), rev'd, 429 U.S. 125 (1976).

${ }^{201}$ See Gilbert v. General Elec. Co., 429 U.S. 125, 145-46 (1976).

202 Id. at 135 (quoting Geduldig v. Aiello, 417 U.S. 484, 496-97 (1974)).

203 See id. at 136.

${ }^{204}$ Pub. L. No. 95-555, 92 Stat. 2076 (codified at 42 U.S.C. $\$ 2000 \mathrm{e}(\mathrm{k})$ (1988)).

20542 U.S.C. $\$ 2000 \mathrm{e}(\mathrm{k})(1988)$.

${ }^{206}$ See 124 CONG. REC. 21,436 (1978); 123 CoNG. REC. 10,581, 29,387, 29,647, 29,655 (1977). 
that the equal treatment approach was necessary, and that special accommodations for pregnant workers would erode equal opportunity for women in the workplace because any special treatment would open the door to inequalities in workplace rights. ${ }^{207}$ Others argued that the biological differences between the sexes should be recognized. Pregnancy should be accommodated because pregnant women experience special needs, and a failure to make special provisions for pregnant workers will create employment barriers for the increasing number of women in the workplace who must leave from time to time for pregnancy and birth. ${ }^{208}$ As Justice O'Connor has described it:

The dilemma is this: If society does not recognize the fact that only women can bear children, then "equal treatment" ends up being unequal. On the other hand, if society recognizes pregnancy as requiring special solicitude, it is a slippery slope back to the protectionist legislation that barred women from the workplace. ... [S]ometimes to treat men and women exactly the same is to treat them differently, at least with respect to pregnancy.

Women do have the gift of bearing children, a gift that needs to be accommodated in the working world. However, in allowing for this difference, we must always remember that we risk a return to the myth of the "true woman" that blocked the career paths of many generations of women. ${ }^{209}$

In 1980, the California legislature adopted the special treatment view, providing that pregnant workers were entitled to an unpaid pregnancy disability leave of up to four months, and that the failure to so accommodate an employee's pregnancy constituted sex discrimination. ${ }^{210}$ In an important extension of the concept of

207 See, e.g., Wendy W. Williams, Equality's Riddle: Pregnancy and the Equal Treatment/Special Treatment Debate, 13 N.Y.U. REV. L. \& Soc. CHANGE 325, 327 (198485) (advocating the equal treatment model in order to avoid creating "structural barriers to the full participation of women in the workforce").

${ }^{208}$ See, e.g., Herma H. Kay, Equality and Difference: The Case of Pregnancy, 1 BERKELEY WOMEN'S L.J. 1, 22-27 (1985) (arguing that reproductive differences between men and women should be recognized during the "temporary episode of a woman's pregnancy"); Ann C. Scales, Towards a Feminist Jurisprudence, 56 IND. L.J. 375,436 (1980-81) ("To account for pregnancy . . . [is] to treat women as equals ... by ceasing to impose on women a bifurcated existence . . . and to restore to women the opportunity to ... integrate[] [a] career and procreation just as ... men [do] . ...").

${ }^{209}$ Sandra Day O'Connor, Portia's Progress, Address at the James Madison Lecture at New York University School of Law, THE RECORDER, Dec. 20, 1991, at 6, 13-14.

${ }^{210}$ See CAL. Gov'T. CODE $§ 12945$ (West 1992). 
discrimination as a failure to accommodate an employee's protected differences, the Supreme Court upheld California's law against a challenge under Title VII in Califormia Federal Savings $\mathcal{E}^{\circ}$ Loan Ass'n v. Guerra. 211

In January, 1982, Lillian Garland, a receptionist at California Federal Savings and Loan Association ("Cal-Fed"), took a pregnancy disability leave. While on leave, Cal-Fed filled her position with a permanent replacement. In April, Garland notified Cal-Fed that she was ready to resume work, but was told that no appropriate positions were available. California's Department of Fair Employment and Housing, on behalf of Garland, alleged that Cal-Fed's disability leave policy violated California law. As the State began an administrative prosecution, Cal-Fed sought a declaration in the United States District Court that the California law violated Title VII by requiring employers to discriminate in favor of pregnant employees on the basis of sex.

The district court agreed, striking down the California law as providing preferential treatment of female employees inconsistent with Title VII's equal treatment purpose. ${ }^{212}$ The Ninth Circuit reversed, holding that the PDA was intended to require employers to include pregnancy disability leave in benefit packages. Because pregnancy disability leave furthers Title VII's purpose of achieving equal employment opportunity, the California law was held permissible under Title VII. ${ }^{213}$

The Supreme Court, in an opinion by Justice Marshall, affirmed the Ninth Circuit's decision, holding that California could provide special accommodation to pregnant employees because Title VII and the California law shared a common goal of equal employment opportunity. By requiring reinstatement after a reasonable pregnancy leave, the California law promotes nondiscrimination on the basis of pregnancy and "allows women, as well as men, to have families without losing their jobs."214

The Court's position was a significant endorsement of a theory of negligent discrimination. The wrong committed under California law was the failure to take special steps, not taken for male workers,

211479 U.S. 272 (1987).

212 See California Fed. Sav. \& Loan Ass'n v. Guerra, No. GIV.A.83-4972R, 1984 WL 943, at *4-*5 (C.D. Cal.), rev’d, 758 F.2d 390 (9th Cir. 1985), aff'd, 479 U.S. 272 (1987).

213 See California Fed. Sav. \& Loan Ass'n v. Guerra, 758 F.2d 390, 396 (9th Cir. 1985), affd, 479 U.S. 272 (1987).

214 Guerra, 479 U.S. at 289. 
to ensure female workers' continuing employment. Liability was assessed not because of an act directed at Garland, but instead because of the failure to accommodate her pregnancy. This focus on liability for the failure to take an affirmative action is a classic example of liability for the failure to carry out a duty imposed by a special relationship. The Court's holding that the PDA did not foreclose the California negligence approach to pregnancy discrimination, focusing on the employer's reasonableness and its obligation to act to prevent harm to its employees, is consistent with the actions of Congress in each case where it has moved to expand a Title VII theory that was previously narrowed by the Court; in the cases of Gilbert, Dewey, Griggs, and Albemarle, Congress has acted to protect a negligence analysis of employment discrimination or to recognize that discrimination need not be intentional to be wrongful.

\section{Accommodation of Disabilities}

The theory of discrimination by a failure to provide reasonable accommodation also finds support in the area of discrimination on the basis of physical or mental disability. The Rehabilitation Act of 1973 prohibits the federal government, federal agencies, federal programs and private employers who receive federal financial assistance from discriminating in various areas, including employment, on the basis of disability. ${ }^{215}$ Administrative regulations $^{216}$ and court interpretations ${ }^{217}$ require employers covered under the Rehabilitation Act to reasonably accommodate the disabilities of employees.

This requirement of accommodation has recently been congressionally recognized and expanded. On July 26, 1990, the Americans with Disabilities Act (ADA) was signed into law. ${ }^{218}$ The ADA applies to most employers, ${ }^{219}$ not just recipients of federal assis-

215 See 29 U.S.C. § 794 (1988).

${ }^{216}$ See, e.g., 45 C.F.R. $\$ 84.12$ (1991) (requiring recipients of federal funds to reasonably accommodate applicants or employees with disabilities).

217 See, e.g., Alexander v. Choate, 469 U.S. 287, 300 (1985) (stating that a grantee covered by the Rehabilitation Act may be required to make "reasonable" modifications to accommodate the disabled).

21842 U.S.C. §§ 12101-12213 (Supp. 1990).

219 The ADA exempts employers with fewer than 25 employees for the first two years that the Act is in effect, and those with fewer than 15 employees thereafter. See id. § $12111(5)(\mathrm{A})$. 
tance. ${ }^{220}$ It provides that employers must make reasonable accommodations to qualified individuals with a disability, unless the accommodation would impose an undue hardship on business operations. ${ }^{221}$ The ADA defines reasonable accommodation to include:

making existing facilities ... readily accessible to and usable by individuals with disabilities; and [] job restructuring, part-time or modified work schedules, reassignment to a vacant position, acquisition or modification of equipment or devices, appropriate adjustments or modifications of examinations, training materials or policies, the provision of qualified readers or interpreters, and other similar accommodations. ... .222

Here again, an employer may be subjected to liability not because of any affirmative or intentionally discriminatory steps it has taken, but instead because it has failed to act affirmatively to protect employees or applicants from harm when it had a duty to do so. Liability cannot be explained under a theory of intentional wrong, nor of strict liability. The analogous common law tort is negligence.

\section{The Development of the Duty to Prevent Harassment}

The conventional view of discrimination law recognizes either two or three theories of employment discrimination: adverse impact, intentional disparate treatment, and, in some cases, failure of accommodation. ${ }^{223}$ Much current employment litigation, however, concerns racial and sexual harassment. ${ }^{224}$ Although harassment cases are sometimes analyzed as disparate treatment cases, ${ }^{225}$ this theory is often irrelevant to the nature of the case, and

${ }^{220}$ See id. \$ 12111(2).

${ }^{221}$ See id. \$ 12112(b)(5)(A).

222 Id. $\$ 12111(9)$.

223 See BARBARA L. SCHLEI \& PAUl Grossman, EMPloyment Discrimination LAW 13-290 (2d ed. 1983). There was considerable discussion in the 1970s of a fourth theory recognized by Schlei and Grossman-present effects of past legal discrimination. However, the passage of time and the Court's determination in International Bhd. of Teamsters v. United States, 431 U.S. 324 (1977), that seniority systems which disadvantage minorities may not be challenged under this theory, have relegated it to an insignificant role. See also EEOC Compl. Man. (CCH) 2075 (Apr. 1985) (listing a fifth theory-retaliation. Although retaliation is a legal wrong under Title VII, the theory under which the wrong is proven is disparate treatment analysis).

224 See 1986-88 EEOC COMBINED ANN. REP. 18-23.

225 See, e.g., Bundy v. Jackson, 641 F.2d 934, 942 (D.C. Cir. 1981) (holding that the "disparate treatment [plaintiff] suffered" by being sexually harassed was based upon 
must be stretched almost beyond recognition. The disparate treatment employment discrimination case focuses on motivation, and is usually proven by comparative evidence. In the typical disparate treatment case, the concern is with whether the employer evaluated a minority or female employee or applicant differently than it did white male employees or applicants because of the plaintiff's race or gender. ${ }^{226}$ Harassment cases don't fit this mode, nor the other two modes of discrimination analysis.

From Title VII's inception, the federal courts have grappled with the problem of on-the-job harassment. Beginning with racial harassment cases in the early 1970s, and increasingly in the 1980s (largely in sexual harassment cases) they have developed a doctrine of unlawful harassment premised on settled principles of negligence law. These cases, unlike disparate treatment cases, focus not on comparisons, but instead on the nature of the harmful conduct: Was it unwelcome? Was it pervasive? Was it hostile? Was the perception of it as hostile unreasonable? Was it known to the employer? The development of a doctrine of harassment as unlawful discrimination, along with the doctrine of liability for the failure to accommodate differences, provides substantial support for the recognition of negligent employment discrimination.

\section{Racial and Ethnic Harassment}

It was in the area of racial and ethnic harassment that the proposition first arose that Title VII created affirmative duties for employers, rather than simply prohibiting them from engaging in acts of discrimination. In a series of administrative decisions in the late 1960 s and early 1970 s, the EEOC began to articulate the nature of this duty. In the first of these cases, the Commission was asked to determine whether there was reasonable cause to believe the Act had been violated where an employer fired a black employee for his inability "to get along with" his white co-employees, who had

her gender, and therefore violated Title VII); Barnes v. Costle, 561 F.2d 983, $990 \mathrm{n}$. 55 (D.C. Cir. 1977) (holding that the supervisor of a female employee who was fired because she rebuked his sexual advances violated Title VII because his behavior was directed at women only, constituting disparate treatment based on gender).

${ }^{226}$ An early sexual harassment case was sufficiently concerned with the role of comparative evidence to note that if the harasser was a bisexual supervisor who made sexual demands on all subordinate employees without regard for their gender, his actions would be outside the scope of the Act. See Barnes, 561 F.2d at 990 n.55. But see Bundy, $641 \mathrm{~F} .2 \mathrm{~d}$ at 942 n.7. This concern has not surfaced in later cases. 
subjected him to racial insults. ${ }^{227}$ The Commission found cause, determining that the "[e]mployer is required to maintain a working environment free of racial intimidation-by positive action where necessary. ${ }^{228}$

A series of opinions in accord followed. Where a white employee was fired after he complained about racial harassment of black co-employees, the Commission explained that the employer was "obliged under this Act to maintain a working atmosphere free of racial intimidation or insult. Failure to take steps reasonably calculated to maintain such an atmosphere violates the Act. ${ }^{\text {229 }}$ Where a supervisor used racial epithets in referring to a black employee, the Commission ruled: "Title VII requires an employer to maintain a working environment free of racial intimidation. That requirement includes positive action where positive action is necessary to redress or eliminate employee intimidation. ${ }^{\text {230 }}$ Where an employer was charged with "tolerating" an atmosphere in which ethnic and racial "jokes" were told, the Commission concluded "that the Company's failure to take reasonable steps to eliminate such actions or to remedy their effects discriminates against Charging Parties and other Negroes and Spanish surnamed Americans because of their race and national origin." 231

These early opinions established that Title VII created at least three related affirmative duties in the area of harassment. Employers are required to: (1) establish and maintain a workplace free of harassment; (2) take steps to eliminate harassment when it occurs; and (3) take steps to redress or remedy harassment when it occurs. Although the Commission did not use the language of negligence, the core concept of a negligent breach of a duty created by a special relationship was present. Employers were expected to prevent racial harassment from infecting the workplace. They were expected to be careful, vigilant, and protective of minority employees in confronting harassment when it occurred. Liability would be

227 See EEOC Dec. No. YSF 9-108 (June 26, 1969), 1973 EEOC Dec. (CCH) 16030. ${ }^{228} \mathrm{Id}$.

229 EEOC Dec. No. 71-969 (Dec. 24, 1970), 1973 EEOC Dec. (CCH) I 6193.

230 EEOC Dec. No. $72-0779$ (Dec. 30, 1971), 1973 EEOC Dec. (CCH) 16321.

231 EEOC Dec. No. 72-1561 (May 12, 1972), 1973 EEOC Dec. (CCH) I 1354; see also EEOC Dec. No. 7405 (July 13, 1973), 6 Fair Empl. Prac. Cas. (BNA) 834, 852 (1974); EEOC Dec. No. CL 68-12-431EU, 2 Fair Empl. Prac. Cas. (BNA) 295, 295 (1971) (finding violation when employer tolerated "Polish" jokes and other harassment directed at foreign-born employees, and noting that participation by coemployee of Polish descent was "unremarkable"). 
imposed when the employer failed to comply with the standard of care established by the statutory prohibition on discrimination, either by failing to establish a harassment-free workplace, or by failing to respond appropriately when harassment occurred. Viewing the employers' obligations in this manner leads to the conclusion that racial harassment is a wrong prohibited by Title VII even in the absence of a specific employment decision, such as a termination. To be harassed because of race is to be deprived of the right to a harassment-free workplace.

This view of harassment as a different kind of Title VII violation received further support from the first reported appellate decision to discuss Title VII liability for on the job harassment, Rogers $v$. EEOC. ${ }^{232}$ Plaintiff Josephine Chavez was terminated from her job with an optical service owned by Rogers. She filed a complaint with the EEOC alleging that her supervisor told her she was being fired not because of her work performance, but because abusive behavior by Anglo employees directed at her had created friction in the workplace; she further alleged that the employer had segregated its customers by race. The EEOC sought discovery from the employer, who argued that Chavez' second claim was not actionable. The district court agreed with the employer, denying any discovery related to the segregation of clients. 233 The Fifth Circuit reversed.

In the lead opinion, Judge Goldberg explained that the complaint described two forms of harassment-the harassment by the co-employees and the harassment caused by being subjected to the racial segregation of customers. On whether racial harassment violated Title VII, Judge Goldberg reasoned:

$[\mathrm{P}]$ sychological as well as economic fringes [benefits] are statutorily entitled to protection from employer abuse, and ... [Title VII] sweeps within its protective ambit the practice of creating a working environment heavily charged with ethnic or racial discrimination.... One can readily envision working environments so heavily polluted with discrimination as to destroy completely the emotional and psychological stability of minority group workers, and ... Title VII was aimed at the eradication of such noxious practices. 234

232454 F.2d 234 (5th Cir. 1971), cert. denied, 406 U.S. 957 (1972). The Supreme Court identified Rogers as the first Title VII harassment case in Meritor Sav. Bank, FSB v. Vinson, 477 U.S. 57, 65-66 (1986).

233 See Rogers v. EEOC, 316 F. Supp. 422, 425-26 (E.D. Tex. 1970).

234 Rogers, 454 F.2d at 238. 
Judge Goldberg's reasoning gave further support to the EEOC view that Title VII liability could be based on an employer's obligation to maintain a workplace free of harassment. If the purpose of Title VII was "the eradication of such noxious practices," the employer's mere failure to prevent the practices, resulting in "a working environment heavily charged with ethnic or racial discrimination, ${ }^{235}$ was itself sufficient to impose liability. Although not fully articulated in Rogers, the principle found in the EEOC administrative decisions and supported by Rogers is that an employer has an affirmative duty to prevent discrimination or harassment from "polluting" the work environment. A breach of that duty resulting in employees being harassed based on their protected status establishes employer liability. Here again, while the word negligence is not used, the statute establishes a standard of reasonable care-a duty to protect employees from racial slurs, abuse, or other harassment.

As additional racial harassment cases were brought, further reasoning from negligence law found its way into the law of on-thejob harassment. The earliest cases were concerned with actual employment decisions in which the harassment somehow contributed to an adverse decision, rather than itself being the actionable conduct. In Rogers, for example, Ms. Chavez's action was filed because of her termination, not because of the harassment. ${ }^{236}$ But the question soon arose whether harassment itself was actionable, even in the absence of an adverse employment decision. This problem can arise when an employee who is being harassed remains on the job, or when a court concludes that an employee who has been terminated was harassed while on the job, but that the termination was not linked to the harassment and was not itself unlawful. A number of early decisions extended the Rogers reasoning that harassment accompanied by no economic damages was nonetheless actionable. ${ }^{237}$

235 Id.

${ }^{236}$ See id. at 236; see also United States v. City of Buffalo, 457 F. Supp. 612, 631-35 (W.D.N.Y. 1978) (concluding that existence of co-employee racial harassment and failure of police commissioner to take strong stand against harassment support finding of pattern and practice of discrimination), modified and affd, $633 \mathrm{~F} .2 \mathrm{~d} 643$ (2d Cir. 1980); Muray v. American Standard, Inc., 373 F. Supp. 716, 717 (E.D. La.) (holding that harassment may be used as evidence that the plaintiff's termination was motivated by racial bias), aff d, 488 F.2d 529 (5th Cir. 1973).

237 See, e.g., Compston v. Borden, Inc., 424 F. Supp. 157, 160-62 (S.D. Ohio 1976) (deciding that verbal religious harassment violates Title VII; despite absence of 
Other early cases confronted the question of employer liability for co-employee harassment. They generally held that such harassment, if not known to management, was outside the scope of the Act. ${ }^{238}$ In essence, these courts concluded that there was no violation of the employer's duty to protect its employees from harassment because the duty was triggered by knowledge of a need to act. Thus, the courts were willing to impose liability for coemployee harassment where the employer knew of the harassment and took no steps or insufficient steps to eliminate it, or where the employer had constructive knowledge, in that it should have known of the harassment. ${ }^{239}$ An employer that knew of harassment negligently breached its duty by failing to act, and an employer that should have known of the harassment negligently breached its duty to protect its employees and to establish and maintain a workplace free of harassment. In the face of harassment sufficiently pervasive that a reasonably protective employer would have known of the problem, lack of knowledge could not be a defense. As one court explained in the related context of an employer's failure to investigate the bonafides of a complaint against a black worker by a racist white co-worker:

adverse employment action or economic damages, employee is nonetheless entitled to nominal damages); United States v. Lee Way Motor Freight, Inc., 7 Fair Empl. Prac. Cas. (BNA) 710, 748 (W.D. Okla. 1973) (finding independent violation of Title VII where employer "allow [s] its hiring or supervisory personnel to refer to [minority employees] in a manner derogatory to their race or national origin"); $c f$. Gray v. Greyhound Lines, E., 545 F.2d 169, 176 (D.C. Cir. 1976) (agreeing that current employees have standing to bring action alleging discrimination in hiring because resulting workforce will have an impact on the work environment and Title VII "grants an employee the right to 'a working environment free of racial intimidation" (quoting EEOC Decision No. 74-84 (Feb. 8, 1975), 1975 EEOC Dec. (CCH) I 6450)).

238 See, e.g., Howard v. National Cash Register Co., 388 F. Supp. 603, 606-07 (S.D. Ohio 1975) (distinguishing employer discrimination from employee prejudice and finding no employer liability where employee shows disrespect to co-employees); Fekete v. United States Steel Corp., 353 F. Supp. 1177, 1186-87 (W.D. Pa. 1973) (finding no liability where employer is ignorant of harassment and responds with corrective measures when informed of incidents).

239 See EEOC v. Murphy Motor Freight Lines, Inc., 488 F. Supp. 381, 386 (D. Minn. 1980) (holding that employer is liable for co-employee racial harassment if it knew or should have known of harassment because employer "has a responsibility to take reasonable affirmative steps to eliminate such incidents"); $c f$. Firefighters Inst. for Racial Equality v. City of St. Louis, 549 F.2d 506, 514-15 (8th Cir. 1977) (concluding that where white employees operate supper clubs on city property from which black employees are excluded, employer must act to prevent the co-employee discrimination), cert. denied sub nom. Banta v. U.S., 434 U.S. 819 (1977). 
Though in reason and justice no employer can be held to answer for the personal mental intent of its employees to resort to racial prejudice; it must, however, stand answerable for notice of racial mistreatment when allowing an unfair discharge to result. When warning of the possible existence of such an anathema arises, it is not exonerating excuse from participating fault to wash ones [sic] hands like Pilate and simultaneously bleat of piety. ${ }^{240}$

Another negligence concept to appear in the racial harassment cases was the problem of contributory fault. In DeGrace $v$. Rumsfeld ${ }^{241}$ the plaintiff, a black firefighter harassed by white coemployees, was terminated for absenteeism when he refused, out of fear, to return to work. In articulating a test for liability, the court held that the termination was unlawful if the fire department supervisors had failed to take adequate steps to correct and/or prevent the harassment and if the plaintiff had acted "reasonably" in explaining why he was not coming to work and in his cooperation with the investigation. ${ }^{242}$ Even in the face of proven harassment, liability would not be imposed if the plaintiff, through his unreasonable actions, had caused the termination.

None of these racial harassment decisions focused on an intent to discriminate by either the harasser or the employer. The employer's liability was based not on an intent to do wrong but rather on a failure to do right. While the harassers' intent to intimidate was apparently assumed in at least some of the decisions, ${ }^{243}$ it was generally not discussed. Given that most of the harassment consisted of the use of racial and ethnic slurs in the presence of, but not directed at, the minority employees, it is hypothetically possible that in at least some cases there was no intent to cause harm to the minority employees, but rather a complete disregard for their well-being. ${ }^{244}$ In some cases that disregard for the rights of others may have been sufficiently reckless to constitute an intentional wrong, but in others it may have been nothing more than a negligent infliction of emotional distress. The distinction was not drawn out in the cases, and the courts appeared

240 Anderson v. Methodist-Evangelical Hosp., 4 Fair Empl. Prac. Cas. (BNA) 33, 35 (W.D. Ky. 1971).

241614 F.2d 796 (1st Cir. 1980).

242 See id. at 804-07.

243 See id. at 800; Anderson, 4 Fair Empl. Prac. Cas. (BNA) at 36.

244 See, e.g., Richard Delgado, Words That Wound: A Tort Action for Racial Insults, Epithets, and Name-Calling, 17 HARV. C.R.-C.L. L. REv. 138, 143-45 (1982) (arguing that racial insults, "except perhaps those that are overheard," are intentional). 
to implicitly recognize that regardless of whether there was an intent to cause harm, the workplace was no longer free of harassment, and causing that harm was wrongful. Thus, not only were employers vicariously liable for intentional wrongful acts by their employees, but where their employees caused harm through insensitivity, poor judgment, and disregard for the rights of others, they would also be found vicariously liable.

In sum, the law of racial harassment which developed during the late 1960 s and the 1970 s was essentially based on the core concepts of negligence. Liability was imposed on employers not for discriminatory employment decisions but for failing to protect their employees from harassment by supervisors or co-employees. Liability was assessed without regard for comparisons between minority and majority group employees, without regard for the intent of the employers in permitting the harassment to occur, without regard for the intent of the harasser, and without regard for the statistical impact of such harassment on the workforce. ${ }^{245}$

\section{Sexual Harassment}

The law of sexual harassment in employment followed a rockier path than that of racial and ethnic harassment. Early sexual harassment cases uniformly rejected the proposition that sexual harassment was actionable under Title VII. These early cases focused on the sex rather than the harassment, and generally declared sexual harassment a "private" matter outside the scope of the Act. But a series of circuit court opinions in the late 1970s and a set of EEOC Guidelines promulgated in 1980 changed the direction of sexual harassment analysis. As sexual harassment was recognized as a violation of Title VII, the scope of liability established under the racial and ethnic harassment cases for an employer's failure to act to prevent harassment was expanded. This expansion was accompanied by a new focus on whether the employee contributed to, or caused, the harassment. Contributory fault, in practice if not in name, came under consideration. Tort law's privilege of consent ${ }^{246}$ was often an issue in litigation, as courts grappled with whether a sexual act directed at an employee was demonstrably unwanted. The question of whether conduct was

215 No reported decision found by the author considered harassment as a neutral practice with a discriminatory effect.

246 See RestATEMENT (SECOND) OF TORTS \$§ 49-62, 892-892C (1977). 
properly termed harassment was subjected to a classic negligence reasonableness test, with two circuits adopting a "reasonable woman" test to analyze whether a victim was reasonable in feeling harassed. ${ }^{247}$

The developing law of sexual harassment has contributed to the development of negligent discrimination in a number of areas. It has helped define those employer duties which, if breached, will constitute negligence. It has clarified the role of traditional respondeat superior liability in the field of employment discrimination law. It has elevated the importance of a reasonableness test in assessing whether conduct is discriminatory, and has provided the basis for a "reasonable woman" test or "reasonable discrimination victim" test in assessing employer (and co-employee) conduct. These developments will be discussed in this subsection.

\section{a. Early Sexual Harassment Cases}

Recognition of what conduct constituted racial harassment was relatively straightforward. While some conduct was judged insufficiently offensive or pervasive to constitute harassnent, ${ }^{248}$ it was generally easy to recognize racial slurs, threats, and disparagements as unwanted and offensive. The question became more complicated when the problem of sexual harassment was considered. Subjecting women to sexual slurs, intimidation, threats and disparagement is readily analogous to the kind of racial harassment the courts were becoming accustomed to, but conditioning employment on sexual demands, harassment through sexual advances, and harassment through suggestive physical touching had no ready analogy in existing employment discrimination law. Moreover, sexual advances could not necessarily be presumed to be

247 See Ellison v. Brady, 924 F.2d 872, 879-80 (9th Cir. 1991); Andrews v. City of Phila., 895 F.2d 1469, 1482 (3d Cir. 1990); see also infra text accompanying notes 297302.

${ }^{248}$ See, e.g., Cariddi v. Kansas City Chiefs Football Club, Inc., 568 F.2d 87, 87-88 (8th Cir. 1977) (holding that occasional references to plaintiff as a "dago" and to Italian Americans as the "Mafia" were insufficiently severe or pervasive to violate Title VII); Kishaba v. Hilton Hotels Corp., 737 F. Supp. 549, 555 (D. Haw. 1990) (finding that no hostile work environment existed where plaintiff failed to establish any "objective" racially offensive conduct directed at herself or occurring in her presence), affd, 936 F.2d 578 (9th Cir. 1991); Robertson v. Georgia Dep't of Corrections, 725 F. Supp. 533, 538-39 (S.D. Ga. 1989) (concluding that plaintiff's allegation, without supporting evidence, that he was removed to an inferior office because of his race and subjected to isolated racial slurs was insufficient to create a hostile work environment). 
unwanted in the way that virtually all racially charged conduct could.

Beginning in the mid-1970s, a number of cases involving such conduct were brought attempting to apply and expand the law of racial harassment to the problem of sexual harassment. In most of these early cases the district courts viewed the conduct as wrongful and potentially tortious, but as lying outside the proper scope of Title VII.

The first reported decision considering the question of whether sexual harassment violates Title VII was in 1975 in Corme v. Bausch E Lomb, Inc. ${ }^{249}$ The case concerned two women who had suffered verbal and physical sexual advances from their supervisor leading to their constructive discharge. The district court dismissed the action, holding that the harassment was not conducted as part of a company policy, but rather as a "personal proclivity, peculiarity or mannerism ... satisfying a personal urge"250 and that if such conduct was actionable there would be a "potential federal lawsuit every time any employee made amorous or sexually oriented advances toward another. ${ }^{251}$ While not using the terminology of vicarious liability for tortious acts by employees, the opinion relies on the familiar tort concept that an employer is not liable for an employee's "frolic and detour." 252

Similarly, in Barnes v. Train ${ }^{253}$ an employee's job was eliminated after she refused to have sex with her supervisor. The district court judge ruled that the conduct was outside the scope of the Act: "Regardless of how inexcusable the conduct of [the plaintiff's] supervisor might have been, it does not evidence an arbitrary barrier to continued employment based on [plaintiff's] sex." ${ }^{254}$ In Miller v. Bank of America ${ }^{255}$ an employee was promised a better job if she had sex with her supervisor. She refused and was terminated. The district court dismissed her action because the employer had a policy against sexual advances by supervisors, and an internal complaint procedure that she had failed to invoke. ${ }^{256}$

249390 F. Supp. 161 (D. Ariz. 1975), vacated, 562 F.2d 55 (9th Cir. 1977).

$250 I d$. at 163 .

251 Id.

252 KEETON ET AL., supra note $123, \S 70$, at 505.

25313 Fair Empl. Prac. Cas. (BNA) 123 (D.D.C. 1974), rev'd sub nom. Barnes v. Costle, 561 F.2d 983 (D.C. Cir. 1977).

${ }^{254}$ Costle, 561 F.2d at 986 (quoting Train, 13 Fair Empl. Prac. Cas. (BNA) at 124).

255418 F. Supp. 233 (N.D. Cal. 1976), rev'd, 600 F.2d 211 (9th Cir. 1979).

${ }^{256}$ See id. at 235-36. 
Again in Tomkins v. Public Service Electric $\mathcal{E}$ Gas Co. ${ }^{257}$ the plaintiff refused her supervisor's sexual advances. She alleged that in retaliation she was transferred, subjected to unwarranted disciplinary layoffs, threats of demotion and pay cuts, and ultimately fired. The Tomkins Court dismissed the action, agreeing with the district court decisions in Corne, Bames, and Miller:

The abuse of authority by supervisors of either sex for personal purposes is an unhappy and recurrent feature of our social experience. Such conduct is frequently illegal under the penal statutes of the relevant jurisdiction. Such conduct might well give rise to a civil action in tort. It is not, however, sex discrimination within the meaning of Title VII even when the purpose is sexual. ... If the plaintiff's view were to prevail, no superior could, prudently, attempt to open a social dialogue with any subordinate of either sex. An invitation to dinner could become an invitation to a federal lawsuit if a once harmonious relationship turned sour at some later time. And if an inebriated approach by a supervisor to a subordinate at the office Christmas party could form the basis of a federal lawsuit for sex discrimination if a promotion or a raise is later denied to the subordinate, we would need 4,000 federal trial judges instead of some $400 .^{258}$

Thus, by the end of 1976 the likelihood of success in the effort to include sexual harassment within the purview of Title VII seemed gloomy.

However, one 1976 decision did find sexual harassment covered by Title VII, and from that point the tide began to turn. In Williams v. Saxbe, ${ }^{259}$ Judge Richey of the District Court for the District of Columbia rejected the arguments of the United States Department of Justice that sexual harassment was outside the scope of the Act. Williams had been fired from her position at the Justice Department on an allegation of poor work performance. She brought a Title VII claim, alleging that the true motive for her termination was retaliation for refusing her supervisor's sexual advances. The court treated the claim as gender discrimination in that male employees were not being subjected to retaliation for refusing the sexual advances of supervisors, and thus within the ambit of Title VII. ${ }^{260}$

257422 F. Supp 553 (D.N.J. 1976), rev'd, 568 F.2d 1044 (3d Cir. 1977).

${ }^{258}$ Id. at 556-57 (footnotes omitted).

259413 F. Supp. 654 (D.D.C. 1976), rev'd sub nom. Williams v. Bell, 587 F.2d 1240 (D.C. Cir. 1978) (reversing on procedural grounds), on remand, Williams v. Civiletti, 487 F. Supp. 1387, 1389 (D.D.C. 1980) (finding violation of Title VII).

260 See Saxbe, 413 F. Supp. at $657-58$ (" $[T]$ he conduct of the plaintiff's supervisor 
By 1977 the tide had turned fully. First, the Fourth Gircuit, reviewing an unpublished district court decision, ruled that "an employer policy or acquiescence in a practice of compelling female employees to submit to sexual advances of their male supervisors" violates Title VII. ${ }^{261}$ Then the District of Columbia Circuit reversed Barnes. ${ }^{262}$ The court reasoned that the decision to eliminate Ms. Barnes' job was sex discrimination if it was motivated by her refusing to submit to her supervisor's sexual demands, because the demands were gender specific. The court noted that her supervisor was not exacting such demands from male employees:

But for her womanhood, from aught that appears, her participation in sexual activity would never have been solicited. To say, then, that she was victimized in her employment simply because she declined the invitation is to ignore the asserted fact that she was invited only because she was a woman subordinate to the inviter in the hierarchy of agency personnel. Put another way, she became the target of her superior's sexual desires because she was a woman, and was asked to bow to his demands as the price for holding her job. The circumstance imparting high visibility to the role of gender in the affair is that no male employee was susceptible to such an approach by appellant's supervisor. ${ }^{263}$

The Tomkins decision was reversed soon after Bames. The Third Circuit concluded that the supervisor's sexual demands constituted a "term or condition of employment" under Title VII; where the employer, directly or vicariously, imposed different terms or conditions on women than men, the Act was violated:

[W] conclude that Title VII is violated when a supervisor, with the actual or constructive knowledge of the employer, makes sexual advances or demands toward a subordinate employee and conditions that employee's job status-evaluation, continued employment, promotion, or other aspects of career developmenton a favorable response to those advances or demands, and the employer does not take prompt and appropriate remedial action after acquiring such knowledge. ${ }^{264}$

created an artificial barrier to employment which was placed before one gender and not the other.").

261 Garber v. Saxon Business Prods., Inc., 552 F.2d 1032 (4th Cir. 1977) (per curiam).

262 See Barnes v. Costle, 561 F.2d 983 (D.C. Cir. 1977).

263 Id. at 990 (footnotes omitted).

264 Tomkins v. Public Serv. Elec. \& Gas Co., 568 F.2d 1044, $1048-49$ (3rd Cir. 1977), rev'g 422 F. Supp. 553 (D.N.J. 1976). 
The Miller decision followed. ${ }^{265}$ Thus, by the end of 1979 four circuits-the District of Columbia, Third, Fourth and Ninth-were in agreement that at least in the case of employment decisions conditioned on supervisorial sexual demands, sexual harassment, like racial harassment, violated Title VII.

\section{b. The 1980 EEOC Guidelines on Sexual Harassment}

In 1980 the EEOG stepped assertively into the fray over whether sexual harassment violated Title VII, and what kinds of conduct constituted sexual harassment. The Commission issued Guidelines supplementing its previously promulgated Guidelines on Discrimination Because of Sex. ${ }^{266}$ The Commission followed the reasoning of the four circuits which had already held that supervisorial demands for participation in sexual activity constituted a violation of Title VII. But the Commission went much further, including provisions which took critical steps toward the development of a theory of negligent discrimination. ${ }^{267}$

The Commission's Guidelines articulated three alternative forms of sexual harassment. The first form was harassment by conditioning employment on the submission to sexual demands. ${ }^{268}$ The classic example is the supervisor's refusal to hire a subordinate employee unless she has sex with him. The second was harassment in the form of basing employment decisions on the submission to or rejection of sexual demands. ${ }^{269}$ A typical example is the employee rejected for a promotion, or terminated, because she refused to have sex with her supervisor, as in Corne, Miller, Bames, Tomkins, and Williams. Both of these forms of harassment are linked to a specific employment decision in which the employee or applicant loses a tangible job benefit because of an unacceptable sexual demand. Because they involve a demand for sex in exchange for employment, they are collectively referred to as quid pro quo sexual harassment.

${ }^{265}$ See Miller v. Bank of Am., 600 F.2d 211 (9th Cir. 1979), rev'g 418 F. Supp. 233 (N.D. Cal. 1976).

${ }^{266}$ Initial Interim Guidelines appeared at 45 Fed. Reg. 25,025 (1980). Following minor amendments, the final Guidelines appeared at 45 Fed. Reg. 74,677 (1980) (codified at 29 C.F.R. $\$ 1604.11$ (1991)).

267 See 29 C.F.R. $\$ 1604.11$ (a)(3),(d), (e), (f) (1991); infra text accompanying notes 270-79.

${ }^{268}$ See 29 C.F.R. § 1604.11(a)(1).

${ }^{269}$ See id. \$ 1604.11(a)(2). 
The Commission also included in its definition of harassment a third type of activity not linked to any direct employment decision. Sexual harassment was also defined to include unwelcome sexual conduct which "has the purpose or effect of unreasonably interfering with an individual's work performance or creating an intimidating, hostile, or offensive working environment."270 This "hostile working environment" theory of harassment, suggested by the racial harassment cases following Judge Goldberg's opinion in Rogers, opened the door to determinations of sexual harassment liability when no specific employment decision was challenged. ${ }^{271}$

To the extent that a hostile work environment resulted from conduct perpetrated by agents and supervisory employees, the Commission's view was that liability should be imposed without regard to an employer's direct knowledge, even when the employer had forbidden such behavior; the act of the agent was deemed the act of the principal. ${ }^{272}$ This view was an extension of the principles expressed in endorsing employer liability for supervisorial quid pro quo sexual harassment in Miller $v$. Bank of America. ${ }^{273}$ In Miller, the Ninth Gircuit considered the role of respondeat superior in the context of employer liability for sexual harassment by a supervisor. The court stated:

The doctrine of respondeat superior has long been routinely applied in the law of torts. It would be shocking to most of us if a court should hold, for example, that a taxi company is not liable for injuries to a pedestrian caused by the negligence of one of its drivers because the company has a safety training program and strictly forbids negligent driving. Nor would the taxi company be exonerated even if the taxi driver, in the course of his employment, became enraged at a jaywalking pedestrian and intentionally ran him down.

Title VII and $\S 1981$ define wrongs that are a type of tort, for which an employer may be liable. There is nothing in either act which even hints at a congressional intention that the employer is

${ }^{270} I d . \S 1604.11(\mathrm{a})(3)$.

271 The first judicial citation to the theory is found in Tomkins v. Public Serv. Elec. \& Gas Co., 568 F.2d 1044, 1046 n.1 (3d Cir. 1977) (decided on other grounds). The theory was advanced by Tomkins' court appointed counsel, Professor Nadine Taub of Rutgers Law School's Women's Rights Litigation Clinic. The theory has been extensively discussed by Catharine Mackinnon. See Catharine A. MacKInnon, THE SEXUAL HARASSMENT OF WORRING WOMEN 40-47 (1979) (describing the facts of several cases involving hostile working environment).

272 See 29 C.F.R. $\$ 1604.11$ (c).

273600 F.2d 211, 213 (9th Cir. 1979). 
not to be liable if one of its employees, acting in the course of his employment, commits the tort. Such a rule would create an enormous loophole in the statutes. Most employers today are corporate bodies or quasi-corporate ones such as partnerships. None of any size, including sole proprietorships, can function without employees. The usual rule, that an employer is liable for the torts of its employees, acting in the course of their employment, seems to us to be just as appropriate here as in other cases, at least where, as here, the actor is the supervisor of the wronged employee. ${ }^{274}$

In the area of supervisorial harassment, the Commission adopted the Miller view and extended it from quid pro quo to hostile work environment harassment.

Having broadly defined harassment, the Commission adopted the view suggested by Judge Goldberg in Rogers that co-employee harassment, even if unauthorized, could establish employer liability for discrimination. ${ }^{275}$ The Guidelines provided that "[w]ith respect to conduct between fellow employees, an employer is responsible for acts of sexual harassment in the workplace where the employer (or its agents or supervisory employees) knows or should have known of the conduct, unless it can show that it took immediate and appropriate corrective action." ${ }^{276}$ Moreover, the Commission stated that "[a]n employer may also be responsible for the acts of non-employees, with respect to sexual harassment of employees in the workplace, where the employer (or its agents or supervisory employees) knows or should have known of the conduct and fails to take immediate and appropriate corrective action. ${ }^{277}$ Thus, liability could be premised merely on the employer's passive failure to act to protect an employee, once it is known (or constructively known) that the employee is being harassed.

This assessment of liability for a passive failure to act to protect those whose protection is required, is a classic example of special

274 Id. (citation omitted).

275 See Rogers v. EEOC, 454 F.2d 234, 238-39 (5th Cir. 1971) (discussed supra text accompanying notes 232-38), cert. denied, 406 U.S. 952 (1972); see also EEOC v. Murphy Motor Freight Lines, Inc., 488 F. Supp. 381, 386 (D. Minn. 1980) (discussed supra text accompanying note 239); $c f$. Firefighters Inst. for Racial Equality v. City of Saint Louis, 549 F.2d 506, 514-15 (8th Cir.) (holding that where white employees operate supper clubs from which black employees are excluded, employer must act to prevent the co-employee discrimination), cert. denied sub nom. Banta v. U.S., 434 U.S. 819 (1977).

27629 C.F.R. $\$ 1604.11(d)$.

27729 C.F.R. § 1604.11(e). 
relationship negligence. The wrongful conduct is not the disparate treatment of males and females as in a McDonnell Douglas analysis, ${ }^{278}$ but rather is the failure to comply with the standard of care created by the statutory duty to affirmatively take corrective action to protect employees from harassment from customers or fellow employees.

Finally, the Commission helped shape the standard of care outside the context of corrective action. The Commission stated:

An employer should take all steps necessary to prevent sexual harassment from occurring, such as affirmatively raising the subject, expressing strong disapproval, developing appropriate sanctions, informing employees of their right to raise and how to raise the issue of harassment under title VII, and developing methods to sensitize all concerned. ${ }^{279}$

Therefore, although the employer's obligation to take corrective action in the case of nonsupervisorial harassment begins only upon constructive or actual notice that harassment is occurring, the failure to take preventative steps provides another potential basis for negligence-type liability.

In sum, the Guidelines promulgated by the EEOC provide an extensive basis for negligence type liability where an employer fails to act to protect its employees from sexual harassment, either by failing to prevent its occurrence or by failing to take corrective steps once it occurs.

\section{c. Meritor Savings Bank v. Vinson}

In 1986, the Guidelines came before the Supreme Court in Meritor Savings Bank v. Vinson. ${ }^{280}$ Given the Rehnquist Court's general hostility toward an expansive reading of civil rights statutes, the broad reading the Guidelines give to sexual harassment law, and the Court's decisions to disregard the EEOC Guidelines on other occasions, ${ }^{281}$ there was good reason to expect the Vinson Court to disavow the Guidelines. Instead, it largely embraced them, and in

278 See supra text accompanying notes 117-23.

27929 C.F.R. § 1604.11(f).

280477 U.S. 57 (1986).

281 The Court has shown no reluctance to disregard the EEOC Guidelines when it disagrees with them. See, e.g., General Elec. Co. v. Gilbert, 429 U.S. 125, 140-45 (1976) (declining to follow EEOC pregnancy discrimination Guidelines); Espinoza v. Farah Mfg. Co., 414 U.S. 86, 94-95 (1973) (declining to follow EEOC ancestry discrimination Guidelines). 
so doing suggested a further willingness to move toward a negligence test for discrimination.

The Vinson case involved hostile work environment harassment by a supervisor of a subordinate employee. Ms. Vinson alleged that after her supervisor hired her, he subjected her to a coercive sexual relationship and various sexually charged humiliating acts. ${ }^{282}$ The district court found that Vinson was not the victim of sexual harassment, reasoning in part that any sexual relationship she had with her supervisor was unrelated to continued employment, advancement, or promotion. ${ }^{283}$ The court further reasoned that even if she had been sexually harassed the bank was not liable for the supervisor's acts because Vinson had not complained or otherwise given notice of the harassment. ${ }^{284}$ The Court of Appeals for the District of Columbia reversed, holding that the district court erred in failing to apply the hostile work environment test, and that if the supervisor engaged in sexual harassment, the employer was strictly liable for his acts. ${ }^{285}$

The Supreme Court completely endorsed the position of the EEOC Guidelines that hostile work environment sexual harassment violates Title VII:

"[U]nwelcome sexual advances, requests for sexual favors, and other verbal or physical conduct of a sexual nature ${ }^{n}$... constitute[s] prohibited "sexual harassment," whether or not it is directly linked to the grant or denial of an economic quid pro quo, where "such conduct has the purpose or effect of unreasonably interfering with an individuals's work performance or creating an intimidating, hostile, or offensive working environment. ${ }^{286}$

The gravamen of the allegation of harassment, the Court explained, is that the sexual advances were "unwelcome." 287

Turning to the question of employer liability, the Court largely adopted the EEOC view, but with one caveat important to the development of negligent discrimination. The Court rejected the

282 See Vinson, 477 U.S. at 60.

283 See Vinson v. Taylor, 23 Fair Empl. Prac. Cas. (BNA) 37, 42 (D.D.C. 1980), rev'd, 753 F.2d 141 (D.C. Cir. 1985), aff'd and remanded sub nom. Mentor Sav. Bank v. Vinson, 477 U.S. 57 (1986).

284 See id.

285 See Vinson v. Taylor, 753 F.2d 141, 147-50 (D.C. Cir. 1985), affd and remanded sub nom. Mentor Sav. Bank v. Vinson, 477 U.S. 57 (1986).

286 Vinson, 477 U.S. at 65 (quoting EEOC Guidlelines, 29 C.F.R. § 1604.11(a), (a)(8) (1985)).

${ }^{287}$ Id. at 68 (quoting 29 C.F.R. $\S 1604.11$ (a) (1985)). 
D.C. Circuit's opinion that an employer is strictly liable for all sexual harassment by a supervisor. ${ }^{288}$ In the case of quid pro quo harassment, when a supervisor offers or threatens the exchange of an employment decision for the grant or refusal of a sexual act, the Court appeared sympathetic to the argument that a strict liability standard should apply. The Court concurred with the EEOC view that agency principles of respondeat superior should apply; ${ }^{289}$ under those principles, a supervisor making or threatening to make decisions affecting employment status is acting with sufficient delegated authority so that his acts may properly be imputed per se to the employer. ${ }^{290}$

Yet on the question of the standard for employer liability for hostile work environment sexual harassment, the Court declined to apply what it termed "automatic liability" or "absolute liability."291 On this question, the EEOC's argument before the Court on how respondeat superior operates was in conflict with the EEOC Guidelines. The Court was asked to choose between the position of strict liability for any agent's acts, as found in the EEOC Guidelines, and the new position taken by the EEOC at the time of the Vinson case. In its amicus curiae brief in Vinson, the EEOC urged the Court to hold that when a supervisor engaged in hostile work environment harassment outside the knowledge of the employer, liability under principles of agency should depend on the extent to which the employer had provided reasonable safeguards to prevent sexual harassment and effective procedures to deal with harassment complaints. ${ }^{292}$ In essence, the EEOC had shifted its view of employer liability for work environment supervisor harassment outside the employer's knowledge toward a "reasonableness" test. ${ }^{293}$ The Court declined to resolve this issue with a "definitive rule," deeming it too abstract and not properly before it given the state of the record. ${ }^{294}$ Nonetheless, it held that employer liability

\footnotetext{
288 See id. at 72.

289 See id.

290 See id. at 70-72.

291 The Court uses both terms interchangeably. See id. at 72-73.

292 See id. at 71.

293 The Vinson Court did not reach the question of employer liability for co employee harassment, but Justice Rehnquist's lead opinion suggested the Court's implicit endorsement of the EEOC Guidelines. The decision read Judge Goldberg's Rogers decision expansively to provide that an employer's discriminatory service to its customers, if it makes the work environment hostile to its employees, violates Title VII. See id. at 65-66.

294 See id. at 72 .
} 
should look at least in part to principles of agency law, and that while absolute liability for supervisorial hostile work environment harassment is too strict, the mere existence of an anti-harassment policy that the plaintiff failed to invoke should not bar her claim. Hence, the Court concluded that some form of respondeat superior vicarious liability, lower than strict liability, was appropriate. ${ }^{295}$

Vinson and the EEOC Guidelines thus encouraged the development of a negligence test for discrimination in four important ways. First, the Court and the EEOC adopted the view that employers have a number of affirmative duties regarding sexual harassment. The employer has a duty to prevent supervisorial quid pro quo harassment; to attempt to prevent supervisorial, co-employee and customer hostile work environment harassment; and to take immediate and appropriate corrective action when any harassment occurs. The breach of any of these duties will establish liability without proof of intent on the part of the employer to do harm. Second, the Vinson Court and the Guidelines endorsed some form of respondeat superior in determining an employer's liability when its supervisors or nonsupervisorial employees pollute the work environment through sexual harassment. This use of the traditional tort test supports the analysis of sexual harassment cases as tort cases. Third, the Vinson Court and the Guidelines adopted the view that in assessing liability, an important factor is the employer's reasonableness in acting to prevent sexual harassment from occurring. The reliance on the traditional negligence reasonableness standard suggests recognition of the development of a negligence test. Fourth, the Vinson Court and the Guidelines endorsed a second reasonableness test in defining what acts constitute sexual harassment. This addresses both the question of whether the conduct was reasonably perceived or experienced as sexual harassment by the employee, and whether it unreasonably interfered with the employee's ability to perform her work. Here again, the language of tort law is invoked, requiring a balancing approach that suggests using negligence doctrine in analyzing the problem.

295 See id. at 73. 


\section{d. Post-Vinson Problems}

A number of the issues arising after Vinson concern these negligence-type problems of "reasonableness." The question arises, for example, when an employer defends a claim of harassment by arguing that the conduct complained of does not rise to the level of offensiveness necessary to deem it harassment. The disagreement is not over whether the plaintiff was subjectively offended by the conduct, but whether her taking offense was objectively reasonable under the circumstances, or whether the alleged harasser acted reasonably. This focus on reasonableness marks, once again, an area in which Title VII law is merging into traditional negligence law. The question of reasonableness is elementary to the question of negligence. In determining whether the defendant breached his or her duty of care, we ask whether the defendant acted as a "reasonable person" exercising "reasonable care" would act under like circumstances. ${ }^{296}$ In the sexual harassment context, we now look both to the reasonableness of the employer's acts, in preventing harassment or taking corrective action, and to the reasonableness of the victim in perceiving or experiencing the acts complained of as harassment.

One recent controversy in this area concerns what standard to apply in determining whether the plaintiff was reasonable in taking offense at the alleged harasser's conduct; in other words, how should a court apply the "reasonable person" test in a sexual harassment case? In the recent case of Ellison $v$. Brady, ${ }^{297}$ the Ninth Circuit rejected the view that reasonableness should be

296 See KeETON ET AL., supra note 123, at 173-75. Although the nomenclature has changed from a "reasonable man" standard to a "reasonable person" standard, it is convincingly argued by several scholars that the standard remains resolutely male. See Leslie Bender, A Lawyer's Primer on Feminist Theory and Tort, 38 J. LEgal Educ. 3, 23 (1988); Dolores A. Donovan \& Stephanie M. Wildman, Is the Reasonable Man Obsolete? A Critical Perspective on Self-Defense and Provocation, 14 LOY. L.A. L. REV. 435, 436 (1981).

297924 F.2d 872 (9th Cir. 1991). A number of other courts have subsequently adopted the Ellison "reasonable woman" standard. See, e.g., Robinson v. Jacksonville Shipyards, Inc., 760 F. Supp. 1486, 1524 (M.D. Fla. 1991) (holding that a reasonable woman would find the working environment at Jacksonville Shipyards abusive); Austen v. Hawaii, 759 F. Supp. 612, 628 (D. Haw. 1991) (preferring a "reasonable woman" standard over a male-biased reasonable person standard), aff"d, $967 \mathrm{~F} .2 \mathrm{~d} 583$ (9th Cir. 1992); see also Sheryl Hahn, Note, Evolution of the Hostile Workplace Claim Under Title VII: Only Sensitive Men Need Apply, 22 GOLDEN GATE U. L. REV. 69, 86-87 (1992) (noting the adoption of the "reasonable woman" standard in Ellison, Robinson, and Austen and discussing its application in the First, Third, and Sixth Circuits). 
measured with reference to generally accepted notions of appropriate behavior: "If we only examined whether a reasonable person would engage in allegedly harassing conduct, we would run the risk of reinforcing the prevailing level of discrimination. Harassers could continue to harass merely because a particular discriminatory practice was common, and victims of harassment would have no remedy. ${ }^{298}$ The Ellison court goes on to define a "reasonable woman" standard, explaining its necessity in sexual harassment cases:

[W]e believe that many women share common concerns which men do not necessarily share. For example, because women are disproportionately victims of rape and sexual assault, women have a stronger incentive to be concerned with sexual behavior. Women who are victims of mild forms of sexual harassment may understandably worry whether a harasser's conduct is merely a prelude to violent sexual assault. Men, who are rarely victims of sexual assault, may view sexual conduct in a vacuum without a full appreciation of the social setting or the underlying threat of violence that a woman may perceive.

In order to shield employers from having to accommodate the idiosyncratic concerns of the rare hyper-sensitive employee, we hold that a female plaintiff states a prima facie case of hostile environment sexual harassment when she alleges conduct which a reasonable woman would consider sufficiently severe or pervasive to alter the conditions of employment and create an abusive working environment. ${ }^{299}$

By contrast, in Rabidue v. Osceola Refining Co. ${ }^{300}$ the Sixth Circuit held that the plaintiff must prove "that the defendant's conduct would have interfered with a reasonable individual's work performance and would have affected seriously the psychological well-being of a reasonable employee. ${ }^{301}$ The EEOC has criticized the Rabidue test, and proposed a reasonable victim test to determine both whether the harassment is sufficiently severe to create an environment hostile to a reasonable victim, and whether the conduct is reasonably perceived as sexual. ${ }^{302}$ The Rabidue test

298 Ellison, 924 F.2d at 878.

299 Id. at 879 (footnotes and citations omitted) (citing Yates v. Avco Corp., 819 F.2d 630 (6th Cir. 1987)). The "reasonable woman" standard was originally proposed in a law review Note. See Note, Sexual Harassment Claims of Abusive Work Environment Under Title VII, 97 HARV. L. REV. 1449, 1451 (1984).

300805 F.2d 611 (6th Cir. 1986), cert. denied, 481 U.S. 1041 (1987).

${ }^{301}$ Rabidue, 805 F.2d at 620 . But see id. at 626 (Keith, C.J., concurring in part, dissenting in part) (dissenting opinion calling for a "reasonable victim" standard).

302 See EEOC Interpretation No. N-915-050 (Mar. 19, 1990), 2 EEOC Compl. Man. 
could not be further from that of Ellison in its sensitivities, nor in its likely impact on litigation. But the two cases share a negligence type of approach to the problem.

Another concept from the law of negligence apparently relied on in Rabidue is the assumption of risk defense. The rule in most jurisdictions allows a person to voluntarily consent in advance to the risk of befalling certain harms, either expressly or by her conduct, thus relieving the defendant of a legal duty of conduct toward her. ${ }^{303}$ In Rabidue, the plaintiff's complaint concerned a coemployee who was "extremely vulgar and crude[,] . . . customarily made obscene comments about women generally, and, on occasion, directed such obscenities to the plaintiff. ${ }^{\text {304 }}$ It also involved a number of other co-employees who displayed offensive and/or suggestive posters of nude women in their offices. ${ }^{305}$ In determining that the plaintiff's work environment was not interfered with sufficiently to constitute sexual harassment, one factor the majority considered, without labeling it as such, was an assumption of risk defense.

[T] he lexicon of obscenity that pervaded the environment of the workplace both before and after the plaintiff's introduction into its environs, coupled with the reasonable expectation of the plaintiff upon voluntarily entering that environment [were factors to weigh]. Thus, the presence of actionable sexual harassment would be different depending upon ... the prevailing work environment. ${ }^{306}$

In other words, when the plaintiff accepted the position, she assumed the risk of being subjected to offensive obscenities because she knew that such conduct prevailed in the work environment.

The application of assumption of risk in Rabidue was criticized in a forceful dissent, ${ }^{307}$ and has been further criticized by the EEOC in an interpretive memorandum. ${ }^{308}$ Its application to sexual harassment is disturbing in part because it deems as

(CCH) 13114 , at 3274 (citing the dissent in Rabidue, 805 F.2d at 626 (Keith, C.J., concurring in part, dissenting in part)).

${ }^{303}$ See generally KEETON ET AL., supra note 123, at 480-98 (analyzing the many aspects of the assumption of risk defense).

${ }^{304}$ Rabidue, 805 F.2d at 615; see also id. at 623-24 (Keith, C.J., concurring in part, dissenting in part).

${ }^{305}$ See id.

${ }^{306}$ Id. at 620.

${ }^{307}$ See id. at 626 (Keith, C.J., concurring in part, dissenting in part).

${ }^{308}$ See 2 EEOC Compl. Man. (CCH) I 3114, at 3274. 
acceptable, if agreed to through an assumption of risk, conduct which has been clearly defined as violative of public policy. Moreover, the Rabidue court did not consider whether the plaintiff, expressly or by conduct, had actually assumed the risk. Rather, the court seemed to hold that, as a matter of law, women assume the risk of harassment if they choose to work in nontraditional settings which are commonly the scene of offensive conduct. This is a misapplication of the doctrine.

The negligence-like problem of reasonableness is also raised in cases determining whether an employer's response to a complaint of harassment is sufficient. The Seventh Circuit, in Brooms v. Regal Tube Co., ${ }^{309}$ held that the proper inquiry is what a reasonable employer would do to remedy the sexual harassment. This is again a clear negligence test. Similarly, the Fourth and Ninth Circuits require the employer to impose a remedy "reasonably calculated to end the harassment. ${ }^{\text {810 }}$ The Brooms standard was criticized by the Ninth Circuit in Ellison, which stated it was adopting the Fourth Circuit test. ${ }^{311}$ Whichever test is adopted, the employer is being held liable for co-employee harassment where the employer's wrongful conduct is merely the failure to respond sufficiently to the harassment.

In another important application of negligence concepts to sexual harassment law, in the wake of Vinson, the Seventh, Eighth, and Ninth Circuits have embraced the EEOC Guidelines on coemployee harassment by taking the position that employers are liable for a mere failure to "prevent a hostile or offensive work environment of which management-level employees knew, or in the exercise of reasonable care should have known." ${ }^{\text {312 }}$ Employer liability for failure to prevent sexual harassment of its employees is classic negligence-type liability. The employer is liable not because it wanted the harm to occur, or helped bring about its occurrence, but because the law imposed on it a duty of care to protect its employees from co-employee harassment, and it failed to take the necessary steps to protect them.

${ }^{309} 881$ F.2d 412, 421 (7th Cir. 1989).

${ }^{310}$ Katz v. Dole, 709 F.2d 251, 256 (4th Cir. 1983); Intlekofer v. Turnage, 973 F.2d 773 (9th Cir. 1992).

311 See Ellison v. Brady, 924 F.2d 872, 882 n.17 (9th Cir. 1991).

312 EEOC v. Hacienda Hotel, 881 F.2d 1504, 1516 (9th Cir. 1989) (citing Hall v. Gus Constr. Co., 842 F.2d 1010, 1015 (8th Cir. 1988), and Hunter v. Allis-Chalmers Corp., Engine Div., 797 F.2d 1417, 1421-22 (7th Cir. 1986)). 
In conclusion, the developing law of sexual harassment under Title VII has borrowed extensively from tort law, and in the process has endorsed the concept of negligent discrimination. Employers are held liable not because they have engaged in intentional wrongs, but because they have failed to conform their conduct to the standard of reasonableness required by their special relationship with their employees, which requires them to use great care in protecting employees from harassment.

\section{CONCLUSION: A THEORY OF NEGLIGENT DISCRIMINATION}

It is a fundamental tenet of our legal system that fault is not equated with an intent to cause harm. We recognize that people often cause substantial harm without any wrongful intent. When the harm is caused as a result of failing to meet a minimum standard of care, which we require to provide ourselves with a reasonably safe and good society, we term that conduct negligence. When employers fail to meet their obligation of due care to protect their employees, and the public, from an undue risk of harm, they are negligent. Duties to use due care to protect employees' health and safety are frequently imposed by statute. ${ }^{313}$ One such duty is the requirement imposed by Title VII to treat employees and applicants equally, without regard to race, color, religion, sex, or national origin. ${ }^{314}$ Employers who, without intending harm, breach this duty by treating women or minorities less favorably than white men, have, in the absence of an available privilege, engaged in negligent discrimination.

Recognition of a negligence theory of employment discrimination under Title VII permits an approach to liability in keeping with the scientific data on discrimination. In a Title VII negligence action, the central question is whether the employer violated its statutory duty to treat minorities and women as it treats white male employees, ${ }^{315}$ or, where a higher duty has been established by the applicable statute, such as a duty of accommodation, to treat them as is required under the higher standard of care. ${ }^{316}$

${ }^{313}$ See, e.g., Occupational Safety and Health Act of 1970, 29 U.S.C. $\$ \S 651-678$ (1988 \& Supp. II 1990) (mandating promulgation of occupational safety and health standards for businesses).

${ }^{314}$ See supra note 1.

315 See supra text accompanying note 226.

${ }^{316}$ See supra Part II.C. 
It is well established that an employer may be liable under Title VII because of its failure to recognize that its selection devices, although facially neutral, are causing a discriminatory impact on minorities or women. ${ }^{317}$ Such liability is premised on the doctrine of negligence. Because Title VII requires the employer to examine its selection devices to assure a lack of discriminatory impact, the failure to do so, if harm is caused, is negligent. Similarly, where an employer recognizes that its facially neutral selection device is having a discriminatory impact, yet fails to take corrective action, it is again negligent. ${ }^{318}$ In requiring employers to take all reasonable steps to mitigate discriminatory selection devices, Title VII imposes negligence liability for this failure to act to prevent harm.

It is well established that where Title VII requires an employer to take special steps to accommodate differences among employees, it is liable when it fails in its duty of accommodation. Such liability is premised on the doctrine of negligence. When an employer is requested to reasonably accommodate an employee's religious beliefs, liability is imposed if it fails to do so, regardless of its state of mind, or its sympathy or hostility towards the employee's religion. ${ }^{319}$ Liability is based on Title VII's affirmative duty to act, which may be violated by the employer's negligent failure either to act at all, or to act sufficiently to meet its legal duties. Similar negligence liability is imposed under the Americans with Disabilities Act when an employer fails to accommodate an employee's or applicant's disability. ${ }^{320}$ Under California law, an employer's failure to accommodate pregnant employees by granting temporary leave, even if it grants no temporary disability leave to male employees, violates the employer's statutory duties. ${ }^{321}$ Liability in such cases is not premised on an intended wrong, but on negligence, the mere breach of a duty imposed by society for the general good.

Although less well established, it should be clear that where an employer makes decisions based on racial, ethnic, or sex-based stereotypes, instead of making an individualized determination, it has violated Title VII. ${ }^{322}$ The violation may be explained based

317 See supra Part II.A.1.

318 See supra Part II.B.I.

319 See supra Part II.C.1.

320 See supra Part II.C.3.

321 See supra text accompanying notes 211-14.

322 Proof that the employer relied on stereotypes may in some cases require 
on a theory of constructive or inferred intent, but this intent is a mere legal fiction. The decision may have been made without any conscious intent to discriminate; it does not matter. Because Title VII bans such differences in treatment, the failure to judge each person on his or her merits is wrongful. Here again, the imposition of liability is premised on negligence; the employer has breached its duty to treat its employees and applicants alike, without regard to race, color, religion, sex, or national origin.

It is well established that where an employer creates or maintains a workplace in which racial or sexual harassment is permitted to interfere with working conditions, the employer is liable for its failure to protect its employees. ${ }^{323}$ Here too, such liability is premised on the doctrine of negligence; the law imposes on the employer a series of duties regarding on-the-job harassment, the breach of which is actionable. If complaints are made against supervisors, co-employees, or customers, the failure to investigate and take corrective measures is negligence. Where an employer knows, or ought to know, that an employee is being improperly harassed, it is negligent in failing to take corrective steps. ${ }^{324}$ Where a supervisor directly harasses an employee, but fails to recognize that his actions constitute harassment, if a reasonable victim would experience it as such, the employer is liable for negligent harassment. ${ }^{325}$

From these well recognized instances of negligence liability under Title VII, it is but a small step to a general application of the principle. Whenever an employer fails to act to prevent discrimination which it knows, or should know, is occurring, which it expects to occur, or which it should expect to occur, it should be held negligent. Liability should also be recognized when an employer breaches the statutorily established standard of care by making

expert testimony regarding the prevalence of certain stereotypes. Relying on studies such as those described in Part I.B, supra, a psychologist or sociologist could testify to the existence of specific stereotypes; the judge or jury could determine whether the stereotypes were applied in evaluating the plaintiff. In other circumstances, a judge or lay jury may be fully capable of recognizing the stereotype applied and discerning its application without assistance. As Justice Brennan noted in Price Waterhouse, it does not "require expertise in psychology to know that, if an employee's flawed 'interpersonal skills' can be corrected by a soft-hued suit or a new shade of lipstick, perhaps it is the employee's sex and not her interpersonal skills that has drawn the criticism." Price Waterhouse v. Hopkins, 490 U.S. 228, 256 (1989).

323 See supra Part II.C.

324 See supra Part II.D.

325 See supra Part II.D. 
employment decisions which have a discriminatory effect, without first scrutinizing its processes, searching for less discriminatory alternatives, and examining its own motives for evidence of stereotyping.

When a woman or minority job applicant is rejected, the rejection should act as a triggering device, requiring the decision maker to instantly stop and examine his or her own motives. If the decision cannot be justified with a reasonable, nondiscriminatory reason, such as bona fide qualifications, the decision may have been negligently reached. If a prohibited basis for decision making played a role in the decision, ${ }^{326}$ consciously or unconsciously, Title VII liability should be imposed.

Where an employer has created job screening procedures which fail to correct for unconscious discrimination, and such discrimination influences the process, the employer ought to be subject to negligence liability. The same standard should apply to employee evaluations, where stereotypes can easily influence subjective evaluations critical to job or career advancement. Similarly, when a female or minority employee is disciplined, the employer ought to take particular care in determining that the decision to impose discipline, and the level of discipline imposed, has not been improperly influenced by discrimination. Where unconscious motivations abound, self-conscious and cautious procedures are necessary.

One social benefit of negligent discrimination stems from the recognition that a finding of liability should not be equated with a determination of moral wrongfulness. In many areas of life our society has recognized the fact that basically "good" people sometimes do "bad" things. We may condemn the act of speeding, for example, and hold the speeder responsible for any injuries caused by the act of speeding, without stigmatizing the speeder as a person. Speeding may be a generally bad thing to do, but speeders are not necessarily bad people. If the speeder is in an accident, we may hold her responsible for the damages caused, even if she meant no harm; indeed, even if she did not intend to speed. The driver who fails to see the speed limit sign and, while driving faster than the posted limit, is involved in an injury-causing

${ }^{326}$ In determining how much of a role discrimination must play to establish liability, see Paul J. Gudel, Beyond Causation: The Interpretation of Action and the Mixed Motives Problem in Employment Discrimination Law, 70 TEx. L. REv. 17, 18-21 (1991) (discussing standard of proof in Title VII cases). 
accident, may be held negligent per se, and thus liable for any resulting injuries. The lack of moral blameworthiness does not translate into a lack of legal responsibility.

Similarly, negligent discrimination need not and ought not to be viewed as morally reprehensible conduct. Employers are confronted daily with many difficult decisions. Even the best will inadvertently fail to exercise due care on occasion, and the winds of chance will cause some breaches to cause harm. When losses occur, the legal system determines where they must fall. In the case of negligent discrimination, actual losses suffered by the employee or applicant should be imposed on the employer, not to punish the employer but to compensate the employee.

Another social benefit of negligent discrimination is its likely impact on employment policies. Imposing negligence liability should have the effect of encouraging greater care, and discouraging those who would look the other way and deny apparent discrimination. Such a consequence is certainly desirable. Prudent employers facing potential negligent discrimination claims are likely to redouble efforts to affirmatively prevent improper harassment and discrimination.

From the employee or applicant's point of view, negligent discrimination cases may be both somewhat easier to prove, and somewhat less satisfying to win. Discrimination litigation today is a modern morality play, focused on the evil motives of the employer. Proving an intentional discriminatory motivation is more difficult than proving a mere failure to have thought critically before acting, but the successful plaintiff is vindicated with a determination that the wrong she suffered was no accident, it was intentional. Given the difficulty of bringing such cases, ${ }^{327}$ vindication is no small matter. A finding of negligence will carry less moral weight, and less stigma for the employer. Such findings, however, are more likely to occur.

Assessing negligence liability also, importantly, places the focus on the discrimination, not the motivation. The effect will be to validate the harm of discrimination as harm worthy of compensation. This benefits both employees, whose suffering is being recognized, and employers, who are no longer being accused of

${ }^{327}$ See Steven A. Holmes, Workers Find It Tough Going Filing Lawsuils over Job Bias, N.Y. TMEs, July 24, 1991, at A1 (late ed.) (reporting the unwillingness of lawyers to represent plaintiffs in employment discrimination cases because of the difficulty of proof and the diminishing likelihood of success). 
bigotry. Negligent discrimination directs its attention toward healing the wounded, rather than assessing blame.

Where truly intentional discrimination occurs, courts should continue to assess liability under an intentional discrimination standard. In these cases a moral stigma will attach, and punitive damages will generally be appropriate. Such damages are available in unlimited amounts in race discrimination cases, ${ }^{328}$ and in amounts up to $\$ 50,000$ to $\$ 300,000$ (depending on the size of the employer $)^{329}$ in sex discrimination cases, in addition to the right to recover back pay, costs and attorney fees. The award of punitive damages is not appropriate without a finding of intent.

For over twenty years, the courts have looked at employment discrimination as a problem of conscious, intentional wrong-doing. Cases involving employer discrimination because of unconscious, but wrongful, motivation, were either dismissed, or squeezed uncomfortably into an intentional tort analysis. In the latter instances, negligence doctrine was frequently utilized, but never explicitly recognized. At best, the result was confusion. At worst, it was the wrongful dismissal of cases in which discrimination was established, but not properly pigeonholed. The time is past due to explicitly recognize that much employment discrimination is the product of employer negligence. Negligent discrimination should be recognized as a central doctrine in the analysis of employment discrimination cases.

${ }^{328}$ See 42 U.S.C.A. § 1981 (West Supp. 1992).

${ }^{329}$ See id. \$ $1981 \mathrm{a}(\mathrm{b})(3)$. 